NBER WORKING PAPER SERIES

\title{
A PRIMER ON REAL EFFECTIVE EXCHANGE RATES: DETERMINANTS, OVERVALUATION, TRADE FLOWS AND COMPETITIVE DEVALUATION
}

\author{
Menzie D. Chinn \\ Working Paper 11521 \\ http://www.nber.org/papers/w11521 \\ NATIONAL BUREAU OF ECONOMIC RESEARCH \\ 1050 Massachusetts Avenue \\ Cambridge, MA 02138 \\ July 2005
}

I thank the editor, George Tavlas, and Sebastian Edwards and Bernd Schnatz for valuable comments and Ron Alquist, Yin-Wong Cheung and Aileen Wong for data, and Oli Coibion and Hiro Ito for research assistance. Faculty research funds of the University of California, Santa Cruz and the University of Wisconsin, Madison are gratefully acknowledged. The views expressed herein are those of the author(s) and do not necessarily reflect the views of the National Bureau of Economic Research.

(O2005 by Menzie D. Chinn. All rights reserved. Short sections of text, not to exceed two paragraphs, may be quoted without explicit permission provided that full credit, including $\odot$ notice, is given to the source. 
A Primer on Real Effective Exchange Rates: Determinants, Overvaluation, Trade Flows and Competitive Devaluation

Menzie D. Chinn

NBER Working Paper No. 11521

July 2005

JEL No. F31, F41

\begin{abstract}
Several alternative measures of "effective" exchange rates are discussed in the context of their theoretical underpinnings and actual construction. Focusing on contemporary indices and recently developed econometric methods, the empirical characteristics of these differing series are examined, including the exchange rates for the U.S., the euro area and several East Asian countries. The issues that confront the applied economist or policymaker in using the measures of real effective exchange rates available are illustrated in several case studies from current interest: (i) evaluating exchange rate misalignment, (ii) testing the Balassa-Samuelson effect, (iii) estimating the price responsiveness of trade flows, and (iv) assessing the potential impact of competitive devaluations.
\end{abstract}

\author{
Menzie D. Chinn \\ Department of Economics \\ University of Wisconsin \\ 1180 Observatory Drive \\ Madison, WI 53706 \\ and NBER \\ mchinn@lafollette.wisc.edu
}




\section{Introduction}

This paper addresses issues that face the practicing open economy macroeconomist as she seeks to translate the concept of the exchange rate from the theoretical realm to that of the real world. It is easy to understand the importance of this process. The exchange rate is the key relative price in international finance; the rapid pace of internationalization in goods and asset markets has only enhanced the importance of this variable. It is more difficult to discern why the process of translation might be difficult. However, as soon as one considers the dimensions along which the real world deviates from some theoretical ones - many countries instead of two, imperfect or no observations on the prices of interest - then the obstacles to real world analysis become clearer. In practice, this issue becomes the selection criteria for the real effective exchange rate measure. As the recent depreciation of the dollar against the euro has demonstrated, bilateral movements can be misleading indicators of the overall decline in the dollar's value. Figure 1 illustrates the fact that the fact that the $33 \%$ depreciation in the dollar/euro rate from January 2002 to the end of 2004 has not been representative of a broad based decline. The Fed's broad index has only registered a 17\% decline by November of 2004.

Although there is an extensive literature on the concepts underlying such measures, many of the relevant works are of an earlier vintage ${ }^{1}$, and do not directly comment upon indices now commonly available. Furthermore, in applied work underlying methods used to calculate the indices are sometimes ignored. This can lead to misleading inferences when econometric techniques of the 1980's and 1990's are applied.

The paper is organized as follows. First, the meaning of "real" is discussed in the context of competing deflators. Second, the process of calculating an "effective" rate is addressed. Then, the characteristics of several real world real exchange rate indices are examined along different dimension. Finally, the uses of real effective exchange rates are demonstrated in several case studies.

\footnotetext{
${ }^{1}$ One very early reference is Maciejeswski (1983). Edwards (1989b) provides an excellent survey very similar in spirit to this one, focused on less developed economies.
} 
The central message of this paper is that the appropriate definition and calculation of the exchange rate depends upon a complicated interplay of the theoretical model of interest and data availability and reliability. ${ }^{2}$

\section{Defining "Real"}

\subsection{Accounting for Relative Prices}

Often the economist will encounter a model wherein the real, or inflation adjusted, exchange rate plays a central role. However, there are a number of real exchange rates, or "relative prices", that appear in the literature, so there is ample scope for confusion. A decomposition of the most standard definition is useful. That is, define a real exchange rate as

$$
q_{t} \equiv s_{t}-p_{t}+p_{t}^{*}
$$

where $s$ is the log exchange rate defined in units of home currency per unit of foreign.

Now suppose the price index is a geometric average of traded and nontraded good prices.

$$
\begin{gathered}
p_{t}=\alpha p_{t}^{N}+(1-\alpha) p_{t}^{T} \\
p_{t}^{*}=\alpha^{*} p_{t}^{N^{*}}+\left(1-\alpha^{*}\right) p_{t}^{T^{*}}
\end{gathered}
$$

where the * denotes the foreign country, and lowercase letters denote logged values of corresponding uppercase letters. Now Then substituting (2) into (1) and re-arranging yields:

$$
q_{t} \equiv\left(s_{t}-p_{t}^{T}+p_{t}^{T^{*}}\right)-\alpha\left(p_{t}^{N}-p_{t}^{T}\right)+\alpha^{*}\left(p_{t}^{N^{*}}-p_{t}^{T^{*}}\right)
$$

Equation (3) indicates that the real exchange rate can be expressed as the sum of three components: (i) the relative price of tradables, (ii) the relative price of nontradables in terms of

\footnotetext{
2 This paper restricts attention to real effective exchange rates. For a discussion of alternative weighting approaches for the nominal value of the dollar, see Chinn (2005).
} 
tradables in the home country, and (iii) the corresponding relative price in the foreign country. For the case where the weights of nontradables in the aggregate price index are identical, the second and third terms can be collapsed into an intercountry relative price of nontradables, viz.:

$$
q_{t} \equiv\left(s_{t}-p_{t}^{T}+p_{t}^{T^{*}}\right)-\alpha\left(\hat{p}_{t}^{N}-\hat{p}_{t}^{T}\right)
$$

where the circumflex denotes the intercountry log difference.

If one assumes the law of one price holds for all goods, and consumption baskets are identical, then all the terms are zero, and PPP holds (since there are no nontradables by definition). That is, the real exchange rate is a constant - not a very interesting condition, from either a theoretical or practical standpoint.

If instead PPP holds only for tradable goods, then only the second term in equation (4) can be non-zero, and the relative tradables-nontradables price is the determining factor in the value of the real exchange rate. Another possibility is that all goods are tradable, but not perfectly substitutable; then one has an imperfect substitutes model. Both terms on the right hand side of equation (4) can take on non-zero values. In either of these cases, there are a large number of variables that could influence each relative price. And of course, there is nothing to rule out both relative price channels as being operative. In popular discussion, all three definitions of "the real exchange rate" are used, sometimes leading to considerable confusion.

\subsection{Which Relative Price to Use?}

Most models of the real exchange rate can be categorized according to which specific relative price serves as the object of focus. If the relative price of nontradables is key, then the resulting models have been termed "dependent economy" (Salter, 1959; Swan, 1960) or "Scandinavian". The home economy is small relative to the world economy, so the tradable price is pinned down by the rest-of-the-world supply of traded goods. Hence, the "real exchange rate" in this case is $\left(p^{N}-p^{T}\right)$, set to achieve internal balance, i.e., the equilibrium in the supply and demand of nontraded and traded goods (see Hinkle and Nsengiyumva, 1999). More generally, the relative price of nontradables move to achieve internal balance in both countries: 


$$
q_{t}^{l}=-\alpha\left(\hat{p}_{t}^{N}-\hat{p}_{t}^{T}\right)
$$

As Engel (1999) has pointed out, it is typically not appropriate to presume that traded goods prices are equalized, especially at short horizons, and perhaps even at long horizons. For many countries, it may be that the variation in the relative price on nontradables is fairly small. In that case, the relevant exchange rate might well be adequately represented by:

$$
q_{t}^{2}=q_{t}^{T} \equiv\left(s_{t}-p_{t}^{T}+p_{t}^{T^{*}}\right)
$$

This definition is most appropriate when considering the relative price that achieves external balance in trade in goods and services. This variable is also what macroeconomic policymakers allude to as price competitiveness -- a weaker domestic currency (in real terms) means that it is easier to sell domestic goods abroad. Of course, it is also true that a higher $q^{T}$ is equivalent to a worse tradeoff in terms of number of the domestic units required to obtain a single foreign unit.

A related concept is cost competitiveness (Marsh and Tokarick, 1996). To see how this variable is related to the preceding one, consider a markup model of pricing:

$$
p_{t}^{T}=\log \left[\left(1+\mu_{t}\right)\left(\frac{W_{t}}{A_{t}}\right)\right]
$$

where $\mu$ is percentage markup, $W$ is the nominal wage rate, $A$ is the labor productivity per hour. $W / A$ is therefore unit labor cost. Re-expressing (6) using equation (7), and assuming that markups are constant $\left(\mu_{t}=\mu\right)$ yields:

$$
q_{t}^{3}=\left[s_{t}-\left(w_{t}-a_{t}\right)+\left(w_{t}^{*}-a_{t}^{*}\right)\right]
$$

(where the constant has been suppressed). In this case, the real exchange rate is the nominal rate adjusted by wages and productivity levels, and in some ways more closely resembles the 
measure of competitiveness as used in popular discussion. As productivity levels rise, the real exchange rate rises (depreciates), ceteris paribus. This definition of the real exchange rate also fits in with a Ricardian model of trade (Golub, 1994).

The discussion up to this point has been couched in terms of a two country world. This is a convenient simplification in that it allows one to abstract from third country effects. The home country's exports are the imports of the foreign country, and vice versa. However, in the real world, a typical country exports to a number of countries, so it is possible to consider exports competing with another country's exports. In this case, one may be interested in competitiveness in third markets. As soon as one allows for this possibility, then one can meaningfully discuss the relative price of home versus foreign exports. In this case, one would define the real exchange rate as:

$$
q_{t}^{4}=s_{t}-p_{t}^{X}+p_{t}^{X^{*}}
$$

\subsection{Comparing Real World Measures}

In deciding which measure of the real exchange rate is the most appropriate, one is often faced between a set of trade-offs. The first is between the theoretically implied measures and the real world counterparts. The second one is between using the most appropriate measure conceptually, and the most readily available data.

In practice, one only has a choice of a few price deflators. At the monthly frequency, they include the consumer price index (CPI), the producer price index (PPI) or wholesale price index (WPI), or export price index. At lower frequencies, such as quarterly, the set of deflators increases somewhat, to include the GDP deflator, and price indices for the components of GDP, such as the personal consumption expenditure (PCE) deflator.

Typically, the CPI is thought of as weighting fairly heavily nontraded goods such as consumer services. Similarly, the GDP deflator and the CPI will include weight in proportion to their importance in the aggregate economy expenditures on nontradables. In contrast, the PPI and WPI exclude retail sales services that are likely to be nontraded.

If one were primarily concerned about issues of internal balance, then some measure of the relative price of nontradables would be useful, i.e., $\left(p^{N}-p^{T}\right)$. The most readily accessible data 
for this purpose is the ratio of the CPI to the PPI. There are a number of deficiencies with this measure, however. The first is that the CPI is an imperfect measure of nontradables prices. If the CPI corresponds to equation (1), and the PPI accurately reflects the price of tradables, then the $\log$ ratio of the CPI to the PPI is

$$
c p i_{t}-p p i_{t}=\alpha\left(p_{t}^{N}-p_{t}^{T}\right)
$$

That is, the greater the share of nontradables in the aggregate index (the CPI here), the closer the $\mathrm{CPI} / \mathrm{PPI}$ ratio approximates the measure of interest. On the other hand, if nontradables are weighted by only one half, then the elasticity of the CPI/PPI ratio with respect to the underlying relative price of nontradables is one-half. In the two country case, calculation of the real exchange rate using CPI's will in theory yield the correct measure of intercountry relative prices. ${ }^{3}$ However, it is unclear of what interest the ratio of the relative nontradables price in one country relative to another is, as it primarily relates to the condition of internal balance in the two countries. Hence, the decision to calculate of the CPI deflated real exchange rate is almost always driven by expediency and data availability rather than an interest in this variable directly (although the financial crisis-early warning system literature constitutes one exception).

For purposes of calculating the relative price of goods and services that are tradable, the preferred measure is the exchange rate deflated by PPIs or WPIs. One drawback of using these indices is that there is considerably more variation in how these price series are constructed across countries, than for the corresponding CPIs. This is of particular concern because variation in the real exchange rate can occur even if the law of one price holds for individual goods, if the weights on those two goods differ in the respective consumption baskets.

The problem of differing baskets applies with even more strength when discussing exchange rates deflated by export price indices. In studies of industrialized economies, where the

\footnotetext{
${ }^{3}$ In practice, there are a number of reasons why this measure will not equal the theoretically implied object of interest. First, CPIs are not calculated using geometric averaging, as is assumed in equation (1). Second, the PPI is likely to include some nontradable goods and services. Third, the PPI does not include the same goods as are included in the CPI.
} 
export baskets consist largely of manufactured goods, such relative prices might have some meaning. However, when one compares the prices of an export basket of an industrialized country against that of a commodity exporting country, it is almost tautologically the case that the baskets of goods are quite different, and the calculated relative price of uncertain meaning.

A second potential drawback of using existing indices of tradable goods is that PPI's and WPI's may include a large component of imported intermediate goods, such that the resulting real exchange rates are not a good measure of competitiveness.

In Figures 2-4, the CPI, PPI and export price index deflated real exchange rates are shown for Hong Kong, Indonesia, Korea and Thailand, all expressed against the US dollar (in units of US\$ per unit of home currency). Hence, treating the non-US economy as the home economy, these series are equivalent to $-\boldsymbol{q}$ in the preceding equations.

There are a number of interesting stylized facts to be gleaned from these figures. First, CPI deflated real exchange rates typically exhibit a more pronounced upward trend (or a less pronounced downward trend) than the corresponding PPI and/or export price index deflated rate. The way the real exchange rate is defined here, the local currency is typically appreciating against the U.S. currency. This pattern is often explained as the outcome of the BalassaSamuelson model, wherein more rapid productivity growth in the tradable sector than in the nontradable sector results in a rise in the relative price of nontradables. Chinn (2000b) demonstrates that indeed productivity differentials are responsible for some of these trends in East Asian real exchange rates, although not all. ${ }^{4}$

In contrast the PPI deflated real exchange rate exhibits a less pronounced trend, in general. That is, over long periods of time, there appears to be less of a tendency for the PPI deflated rate to move upward. That being said, it is definitely true that PPI and CPI deflated exchange rates covary substantially at the monthly or even quarterly frequency. It more difficult to discern patterns in export price deflated real exchange rates, given their considerable variation.

\footnotetext{
${ }^{4}$ For a dissenting view on the role of the relative price of nontradables in East Asian exchange rates, see Isard and Symanski (1996) and Parsley (2001).
} 


\section{Real Exchange Rates in a Multi-Country World}

\subsection{The Selection of a Weighting Criterion}

In theoretical work, the discussion of the real exchange rate typically abstracts from how to deal with the fact that countries trade with multiple partners. In practice, some sort of weighted, or "effective" measure is used. By far the most common means of calculating an effective real exchange rate is to weight the currencies by trade weights. This simple statement hides a number of complications. First, does one use export weights, import weights, or both? Second, what does one do about third markets - that is how does one measure real exchange rates when one wishes to measure relative prices between home country and foreign goods in a third foreign country? Third, how does one account for time variation in trade weights?

To formalize the discussion, consider a geometrically weighted average of bilateral real exchange rates. ${ }^{5}$ Using our previous notation, where

$$
q_{t}^{R E R 1} \equiv \sum_{j=1}^{n} w_{j} q_{t}^{j}
$$

where $q^{j}$ denotes the log real exchange rate relative to country $\mathrm{j}$. This can be re-expressed in levels

$$
Q_{t}^{R E R 1} \equiv \prod_{j=1}^{n}\left(Q_{t}^{j}\right)^{w_{j}}
$$

There are two questions to be addressed at this point. The first is the nature of the real exchange rate (CPI, PPI, export price index). The second is the one alluded to earlier - how to calculate $w_{j}$. The simplest approach is to use weights based upon bilateral trade volumes (the sum of exports and imports, expressed as a proportion of total exports and imports). One problem with

\footnotetext{
${ }^{5}$ Arithmetically averaged indices are seldom used since such indices possess undesirable characteristics. For instance, changes in the index will differ in percentage terms, depending upon whether the exchange rates are expressed in units of foreign currency per domestic, or vice versa.
} 
this approach is that there is no theoretically implied manner in which to account for changing trade flows.

Trade weighting can take on a more complicated form to allow for competition in third markets. For instance, the Federal Reserve Board, the ECB, the BIS and the IMF construct their real effective exchange rate attempting to capture third market effects.

To see how this is accounting is accomplished consider the following stylized model based upon the IMF's methodology. There is only one type of good, but it is differentiated by country of source. The degree of substitutability of this good is the same, regardless of what type of the country the good comes from. This Armington (1969) assumption is a common feature of effective exchange rate indices. The weight to be used in equation (11) can then be expressed as:

$$
\begin{aligned}
& w_{j}=(\text { imports of } i \text { /imports and exports of } i) \times(\text { share of } i \text { imports from } j) \\
& +(\text { exports of } i \text { /imports and exports of } i) \times(\text { overall export weight })
\end{aligned}
$$

where

$$
\text { overall export weight }=\beta \times(\text { share of exports of } i \text { to } j \text { out of total } i \text { exports })+(1-\beta) \times(\text { third } \text { market weight })
$$

The third market weight is equal to the weighted average over all third-country markets of country j's import share divided by a weighted average of the combined import share of all of country i's competitors, with the weights being the shares of country i's exports to the various markets. ${ }^{6}$

Hence, effective exchange rates that take into account the substitutability between goods sourced from different countries can be calculated from trade data in principle. However, the appropriateness of these measures relies upon a constant elasticity of substitution (CES) function for utility. This selection of utility function is driven by tractability - nothing guarantees that utility is CES in form, and nothing guarantees that a widget exported from the Euro area is equally substitutable with a widget from Malaysia. Spilimbergo and Vamvakidis (2003) investigate whether the CES assumption over all countries is plausible, and find that it is helpful

\footnotetext{
${ }^{6}$ A detailed derivation is contained in Zanello and Desruelle (1997).
} 
to distinguish between OECD and non-OECD countries in constructing effective exchange rate indices.

An even more ideal measure of the effective exchange rate would attempt to use estimated measures of the elasticities. However, such calculations are beyond the data capabilities of most statistical agencies. ${ }^{7}$

\subsection{Time Varying Weights}

Once one has settled on the theoretically interesting weighting scheme, one confronts the matter of allowing for time variation. Clearly, trade flows change over time, so in principle the corresponding trade weights should change. The more rapid the evolution of trade patterns, the more likely it is that a fixed weight index will misrepresent the impact of exchange rate changes. See Bayoumi et al. (2005) for a discussion of how updated weights modify the interpretation of three recent currency events.

One can either allow the weights to change over time continuously or discretely and infrequently, with the choice depending in large part upon the tradeoff between convenience and accuracy. The IMF takes the latter approach, while the Fed adopts the latter. The Federal Reserve calculates its dollar index as:

$$
R_{t}^{F R B} \equiv R_{t-1}^{F R B} \prod_{j=1}^{n}\left(R_{t}^{j} / R_{t-1}^{j}\right)^{w_{j, t}}
$$

(where $\mathrm{R} \equiv 1 / \mathrm{Q}$ is the value of domestic currency). The weight $w_{j, t}$ evolves on an annual basis (Loretan, 2005).

Ellis (2001) describes in greater detail the various methods for allowing time variation in the weights. The ideal method would involve a Tornqvist index. However, such indices require next period's weights, so calculation of such indices would not be possible in real time. Given

\footnotetext{
7 An instance of this approach is the now defunct Multilateral Effective Exchange Rate Model (MERM) (Black, 1976; Artus and Mcguirk, 1981).
} 
the slow moving nature of trade flows, chained Laspeyres (base year weighted) indices are probably a good approximation to the ideal indices.

\subsection{Empirical Comparisons}

In Figure 5, the CPI deflated indices reported by the IMF and the Federal Reserve Board for the value of the U.S. dollar are displayed. Despite the fact that the country coverage is slightly different (this is the "major currencies" index (Loretan, 2005)), the indices track each quite well. Of course, they are not exactly identical. The adjusted $\mathrm{R}^{2}$ from a regression of the $\log$ difference of the IMF series on the log differenced FRB series is 0.95, while the slope coefficient is 0.87 .8

What appears to be of more importance for the United States dollar is the choice of price index. The IMF calculates two real exchange rate series for the U.S. - the CPI deflated and unit labor cost deflated, depicted in Figure 6 (the JP Morgan PPI deflated series could be included, but follows very closely the CPI deflated series, and so is omitted for clarity). Because the U.S. experienced substantially more rapid productivity growth than its trading partners, the dollar experiences real depreciation (in unit labor cost terms) from March 1985 until early 1995, while the CPI deflated series shows a leveling off in 1990. While both series show a dollar appreciation starting in 1995, they tell remarkably different stories about the relative cost positions of U.S. firms. In particular, after accounting for productivity changes, the dollar at the end of 2001 is less than $20 \%$ weaker than its 1985 peak using the CPI deflated rate, while the unit labor deflated series is $40 \%$ weaker. In other words, a radically different picture of the strength of the currency is obtained depending upon the variable used. Figure 7 depicts the CPI, PPI and unit labor cost deflated indices for Japan.

The advent of monetary union in Europe has instigated the calculation of a number of effective exchange rates for the euro. Figure 8 presents the CPI, PPI and unit labor cost deflated measures of the euro (the CPI and unit labor cost measures are from the IMF, while the PPI

\footnotetext{
${ }^{8}$ Another U.S. dollar index calculated by the Atlanta Fed accounts for a wider set of trading partners than does the FRB index (Acree, 1999).
} 
deflated measure is from the ECB). ${ }^{9}$ The CPI and PPI measures do not diverge substantially, while the unit labor cost measure deviates substantially from the other two during the post-1997. By this measure, the euro's descent since its inception in January 1999 was even more precipitous than that implied by price based measures. The latter records a $13 \%$ decline up until February 2002, while the former indicates an $18 \%$ fall. Hence, euro zone cost competitiveness improved more than was suggested by the price deflated real exchange rate.

Unfortunately, unit labor costs are not always available on a timely or consistent basis. Hence, in general trade weighted indices are usually constructed using either CPI's or PPI's. Figures 9-12 depict the trade weighted real exchange rates for Hong Kong, Indonesia, Korea and Thailand. It is difficult to discern any clear pattern amongst all these series, although it is safe to say that most do not appear to be mean stationary. Visually, there appear to be deterministic time trends in some of the series, although we know from the econometric literature on real exchange rates that such ocular regressions may lead to misleading inferences.

\section{Selected Applications}

As is apparent from the preceding discussion, there are numerous measures of effective exchange rates. There is no simple answer to the question of which one is the best. Rather, the selection of the effective exchange rate measure depends upon the economic issue being analyzed. That can best be demonstrated by recounting several recent analyses incorporating effective exchange rate measures.

\subsection{As a Factor in Determining Currency Crises: Overvaluation}

One recent use real exchange rates has been as an indicator of incipient currency crises. Goldfajn and Valdes (1999) document that most medium to large real appreciations are reversed

\footnotetext{
${ }^{9}$ Interestingly, the weighting scheme does not appear to matter very much. The CPI deflated series from the IMF and the ECB "narrow" and "broad" indices all exhibit the same pattern of movement. Appendix Table 2 in Appendix 2 describes the other characteristics of these indices, as well as those calculated by the BIS and ECFIN.
} 
by nominal devaluations/depreciations. Exploring this avenue, Chinn (2000a) considers East Asian exchange rate overvaluation from the perspective of purchasing power parity. Contrary to the views taken in many of the papers on the subject circulating after the crisis, ${ }^{10}$ I argue that calculating exchange rate overvaluations as a deviation from an estimated time trend is not a valid procedure unless the time series being examined are $I(0)$ variables. ${ }^{11}$

It turns out that in most cases, pre-1997 East Asian trade weighted real exchange rates do not appear to be $\mathrm{I}(0)$ processes; hence, the standard practice of calculating exchange rate misalignments as deviations from estimated mean or trend was not justified. Table 1, drawn from Chinn (2000a), illustrates how rare it is for trade weighted indices to be mean stationary. Allowance for deterministic trends does not yield substantially more evidence for stationarity, either using the Johansen (1988) and Johansen-Juselius (1990) methods, adjusting for finite sample critical values (Cheung and Lai, 1993), or the Horvath-Watson (1995) procedure.

In some respects, this result is unsurprising. The finding of stationarity is rare enough for bilateral exchange rates. The trade weighted exchange rates are merely versions of these rates averaged across a number of trading partners, so unless the stationarity for bilaterals is much more pronounced for non-US and non-Japan based exchange rates, one would expect to find similar results. ${ }^{12}$ Furthermore, the CPI deflated series generated by the IMF give a fairly heavy weight to nontradables prices, so nonstationarity is to be expected. On the other hand, the PPI deflated series from J.P. Morgan experience a large weighting shift at the end of 1986.

One exception to this finding is the PPI deflated Hong Kong currency. According to a Horvath-Watson (1995) test applied to the period 1975-1996, this index was stationary (Chinn, 2000a). The estimated mean (displayed in Figure 24) implies an overvaluation of $20 \%$ in May 1997. Extending the sample from that used in Chinn (2000a) indicates that the real effective

\footnotetext{
${ }^{10}$ E.g. Kaminsky and Reinhart (1999) and Frankel and Rose (1996). Chinn, Dooley and Shrestha (1999) use estimated deviations when they are justified by the cointegration tests.

${ }^{11}$ See Breuer (1994) for a discussion of the distinction between finding trend stationarity, and the concept of relative PPP. Both Breuer (1994) and Rogoff (1996) provide good surveys of the empirical literature on PPP.

12 See for instance Phylaktis and Kassimatis (1994), Fukuda and Kano (1997) and Lee (1999).
} 
exchange rate has reverted toward its mean, ending 2001 overvalued by $14 \%$ (after going as high as $25 \%$ above).

\subsection{As a Dependent Variable: Productivity}

One use of effective exchange rates is as a summary measure of relative prices, to be explained by any variety of factors. For example Williamson (1994) and Hinkle and Montiel (1999) for eclectic approaches. Edwards (1989a) examines the implications of economic reforms in emerging markets on the equilibrium effective exchange rate. Hsieh (1982), DeGregorio and Wolf (1994) and Chinn (2000b) investigate the determinants of effective real exchange rates focusing on productivity. Specifically, Hsieh utilizes productivity differentials in the BalassaSamuelson framework as explanatory variables for the Yen and DM. To see this take equation (5), repeated here:

$$
q_{t}^{I}=-\alpha\left(\hat{p}_{t}^{N}-\hat{p}_{t}^{T}\right)
$$

If the relative price of nontradables is determined by the relative productivity levels in the two sectors:

$$
\left(p_{t}^{N}-p_{t}^{T}\right)=\left(a_{t}^{T}-a_{t}^{N}\right)
$$

then equation (5) becomes: ${ }^{13}$

$$
q_{t}^{l}=-\alpha\left(\hat{a}_{t}^{T}-\hat{a}_{t}^{N}\right)
$$

13 The following specification holds if the production functions in the two sectors are identical. If the labor share of income in the nontradable sector exceeds that of the tradable sector, then the coefficient on $a^{T}$ would be greater than that on $a^{N}$ in absolute value. 
Hsieh found evidence for a productivity effect - that is, the faster productivity growth is in the tradable sector, the more the currency tends to appreciate in real terms. DeGregorio and Wolf, and Chinn examine a wider set of variables - such a productivity differentials, government spending, per capita income, oil prices - for a panel of 14 OECD real effective exchange rates. Both papers report a productivity effect in panel regressions.

The real effective exchange rate of the euro has been a recent target of investigation. Often, these analyses are couched in terms of behavioral equilibrium exchange rate (BEER) models (Clark and MacDonald, 1999). This specification incorporates variables suggested by different theoretical frameworks, including this Balassa-Samuelson motivation. One prominent example of this approach is Maeso-Fernandez et al. (2002). They find that a one percentage point change in the productivity differential results in a 4 to 5 percent real appreciation of the euro. This is a rather large effect, in fact larger than that implied by the Balassa-Samuelson model. ${ }^{14}$

\subsection{As an Independent Variable: The U.S. Trade Deficit}

The estimation of trade balance relationships has taken on heightened importance, as the U.S. trade deficit has increased to over 5\% of GDP in 2002. A critical question then is whether changes in the real exchange rate will manifest themselves in a commensurate adjustment in volume of trade flows. There is an enormous literature on the subject, and even the number of papers incorporating advances in econometrics (Rose, 1991; Marsh and Tokarick, 1996; and Johnston and Chinn, 1996) is large. Chinn (2004) tackles this issue, using more recent data and estimation methods.

Consider an imperfect substitutes model, as laid out by Goldstein and Khan (1985). This partial equilibrium model yields the familiar import and export functions that comprise the conventional open economy macro model,

\footnotetext{
${ }^{14}$ Maeso-Fernandez et al. (2001) use GDP/employee as their proxy for productivity. As such, the variable does not really conform to the Balassa-Samuelson formulation, as that model relies upon the intercountry intersectoral productivity differential. They also estimate the model using a price proxy (that is, equations 5 and 9 combined), and obtain slightly smaller elasticities, ranging from 1.8 to 3 .
} 


$$
\begin{aligned}
& i m_{t}=\beta_{0}+\beta_{1} q_{t}+\beta_{2} y_{t}^{U S}+\varepsilon_{2 t} \\
& \text { ex }=\delta_{0}+\delta_{1} q_{t}+\delta_{2} y_{t}^{R o W}+\varepsilon_{1 t}
\end{aligned}
$$

where $\delta_{1}>0$ and $\delta_{2}>0$ and $\beta_{1}<0$ and $\beta_{2}>0$.

In words, increases in the relative price of domestic goods relative to foreign goods causes the quantity of imports to fall and those of exports to rise. Domestic economic activity induces an increase in imports, while an increase abroad stimulates exports, ceteris paribus. Underlying these equations is an assumption that import and export supply curves are both perfectly elastic.

Chinn estimates these relationships for the multilateral U.S. trade flows over the 1975q1$2003 q 2$ period. The empirical measures were real imports and exports of goods and services (1996 chain weighted dollars); these series are graphed in Figure 13. Domestic economic activity was measured by U.S. GDP in 1996 chain weighted dollars. Foreign economic activity was measured by Rest-of-World GDP (expressed in 1996 dollars). This measure of rest-of-world GDP is weighted by U.S. exports to major trading partners.

Of central interest is the real effective exchange rate index used. In this analysis, three different exchange rate indices were utilized: the Federal Reserve Board's major currencies trade weighted exchange rate; the J.P. Morgan broad trade-weighted real exchange rate, deflated using the PPI; and the IMF's trade-weighted real exchange rate deflated using unit labor costs. All three series are shown in Figure 14 (rescaled to equal 0 in 1973q1).

The regression results for exports of goods and services are reported in Table 2. Overall, the results are favorable toward a finding of a long run relationship; in all cases evidence of cointegration is obtained, according the trace and maximal eigenvalue statistics. The sensitivity of exports to the real exchange rate is 2.3 when using the CPI deflated measure, and slightly lower - 1.9 - when using the PPI deflated measure. These are quite high estimates, relative to those reported by Hooper et al. (1998), although the standard errors are very large. Overall, income sensitivity estimates are relatively robust. They range from 1.7 to 2 . The price sensitivity is somewhat smaller when identified using the unit labor cost measure. In this case, the price 
sensitivity is 0.7 . The price coefficients all appear to be statistically significant, while only in the unit labor cost case is the income coefficient statistically significant. ${ }^{15}$

The error correction coefficients in the bottom panel of Table 2 indicate that both export flows and GDP respond to disequilibria in the long run export relationship, except in the PPI deflated real rate case. The rate at which exports respond to disequilibrium is about $17 \%$ per quarter in the ULC case.

It is worthwhile spending some time considering which specification is most relevant, since there appears to be evidence of a long run relationship in all three cases. The most readily interpretable specification involves the unit labor cost deflated real rate, as the results rather unambiguously indicate the presence of only one cointegrating vector, and a substantial response of export flows to both income and exchange rates.

The results are somewhat less promising for imports. As shown in columns 1-3 of Table 3 , it turns out it is not possible to identify a statistically significant effect for the real exchange rate, regardless of the real exchange rate measure used. ${ }^{16}$

After some experimentation, following the lead of by Lawrence (1990) and Meade (1991), it turns out that imports excluding computers, computer parts and peripherals, can be modeled without reliance upon a structural break. Economically speaking, this result makes sense given the boom in trade in computers and parts since 1995 combined with rapid changes in computer prices have probably altered the underlying demand relationships (Council of Economic Advisers, 2001). ${ }^{17}$

Column 4 of Table 3 reports estimates using this alternative measure of imports of goods and services. In this case, a long run relationship is detected. The income sensitivity is in line with other estimates, and the price sensitivity, while small, it is plausible and borderline significant. Chinn (forthcoming) finds that computer and computer part imports are unexplained

\footnotetext{
15 The conclusions regarding statistical inference are based upon likelihood ratio tests for zero restrictions in the cointegrating vector.

16 In previous empirical work using a shorter sample period ending at 2001q2, evidence of cointegration is detected only if an exogenous dummy is imposed at 1995q1 (results not reported; see Chinn, forthcoming). Since the economic meaning of such an intervention variable is difficult to discern, this approach is not further pursued in this paper.

17 Nominal computers and computer parts accounted for a peak of $7 \%$ of total imports in 2000 , declining to about $5 \%$ in 2003 . As early as 1980 , the proportion was less than $1 / 2$ of $1 \%$.
} 
by movements in the PPI deflated real exchange rate, suggesting that aggregation of noncomputer and computer imports is inappropriate.

The implication of these findings is that, in certain instances, matching the relevant real effective exchange rate to the problem may require adjustment of the other variables one is examining. In this case, it appears that the aggregate imports variable needs to be redefined so that the trade flow corresponds to the available price index. ${ }^{18}$

\subsection{The Potential for Competitive Devaluation in the Pacific Basin}

One prominent set of debates has centered upon the strategic interaction between Japanese and Chinese economic policymakers. When the Japanese yen has depreciated against the dollar from 108 in November of 1999 to 135 in February 2002, anxieties mounted about whether the resulting pressure on Chinese exports would prompt a devaluation of the RMB.${ }^{19}$ Similar fears could resurface in the event of a new yen decline.

Evaluation whether this scenario was - or is - plausible requires an assessment of both political and economic factors. It is the latter part that effective exchange rate indices can shed light upon. However, the analyst is hampered in this case by the shortcomings of the widely available exchange rate indices. One would like to have good measures on Japanese and Chinese competitiveness, vis à vis their trading partners. Unfortunately, the IMF series are not ideal for this purpose, because of the use of CPI's that include nontradable prices. On the other hand, J.P. Morgan only recently began reporting a Chinese series, and including Chinese trade flows in the calculation of its effective exchange rate indices. Similarly, Deutsche Bank reports a series incorporating Chinese price and exchange rate data and trade weights based on bilateral flows.

\footnotetext{
${ }^{18}$ One can imagine adjustments along different dimensions. For instance Cheung (2003) finds that for Hong Kong exports, it is important to distinguish between domestic exports and reexports as the relevant measure of trade flows; furthermore, he finds that it is essential to use export price deflator than the typically used CPI deflated real effective exchange rate.

${ }^{19}$ In particular, the Chinese maintained the renminbi's (RMB's) de facto peg against the dollar during the 1997-98 East Asian crisis. This policy is perceived to have prevented further rounds of competitive devaluation by other East Asian countries.
} 
As illustrated in Figure 16, the Deutsche Bank series tracks the IMF series at high frequencies over the 1990-2001 period, but exhibits a more pronounced appreciation.

In tackling the issue of competitive pressures, it is very difficult to dodge the question of whether the CES assumption is appropriate for generating the weights in calculating the real effective exchange rate. It is instructive at this point to recall that the weights are calculated in standard effective exchange rate measures using trade flow data. These trade flow data stand in for the theoretically desirable weights of demand elasticities, only by virtue of the assumption that all goods sourced from different countries are equally substitutable (i.e., have the same demand elasticities). This is a convenient assumption that considerably simplifies the construction of a large number of effective exchange rates, but in the current context, one has to seriously question whether a car produced by Japan is a good substitute for a car produced by Korea, and similarly, whether a machine tool made by Japan is a good substitute for a machine tool made by China. ${ }^{20}$

Spencer and Wong (2002) have discussed the characteristics of a series of real effective exchange rate indices calculated using estimated elasticities. Such estimates suggest somewhat smaller weights upon the Japanese yen than simple bilateral trade flows would indicate. For instance, in their simple trade weighted index for China, Japan has a 0.22 weight, while the weights based on bilateral competition and estimated elasticities suggest a weight that is no greater than 0.10 . Furthermore, the corresponding weight for an index focused on competition in third country markets is 0.15 . As a consequence, they conclude that movements in the Japanese yen/US\$ exchange rate have much less impact than popularly thought. ${ }^{21}$

${ }^{20}$ Fernald, Edison and Loungani (1999) took up this issue in an earlier context of examining whether the 1994 Chinese devaluation spurred the East Asian crises of 1997. They compared the composition of Chinese and Southeast Asian exports, and how likely they were to be in direct competition, and concluded that the scope for such interaction was limited.

${ }^{21}$ Of course, any of these conclusions are specific to the particular model underlying the calculation of the effective exchange rate indices. For example Ito, Ogawa and Sasaki (1998) and Ogawa and Ito (2000) have forwarded models strategic firm behavior and a role for imported inputs (an issue largely ignored in this paper). The conclusions regarding the weights to use in calculating the effective indices would naturally differ from the standard measures. 


\section{Conclusions}

In discussions of macroeconomic interactions between economies, the real exchange rate is often the key variable of interest. This paper has laid out the general principles underlying the appropriate deflators and appropriate weighting schemes for differing economic issues. The choices that will be made will depend upon the economic issue at hand, constrained by the availability of data. One important conclusion is that the commonly used indices may be inadequate for the task at hand. In such cases, one may have to generate the effective exchange rate index specific to the task at hand. 


\section{References}

Acree, Bryan, 1999, "Revising the Atlanta Fed Dollar Index," Economic Review 1999Q3 (Federal Reserve Bank of Atlanta): 40-51.

Armington, Paul, 1969, "A Theory of Demand for Products Distinguished by Place of Production," IMF Staff Papers 6: 159-78.

Artus, Jacques R.; McGuirk, Anne K., 1981, "A Revised Version of the Multilateral Exchange Rate Model," International-Monetary-Fund-Staff-Papers 28(2): 275-309.

Balassa, Bela, 1964, "The Purchasing Power Parity Doctrine: A Reappraisal," Journal of Political Economy 72: 584-596.

Bayoumi, Tamim, Jaewoo Lee, and Sarma Jayantha, 2005, "New Rates from New Weights," Working Paper WP/05/99 (Washington, DC: IMF, May).

Black, Stanley W., 1976, "Multilateral and Bilateral Measures of Effective Exchange Rates in a World Model of Traded Goods," Journal of Political Economy 84(3): 615-22.

Breuer, Janice Boucher, 1994, "An Assessment of the Evidence on Purchasing Power Parity," in John Williamson (ed.), Estimating Equilibrium Exchange Rates (Washington, DC: Institute for International Economics): 245-277.

Buldorini, Luca, Stelios Makrydakis and Christian Thimann, 2002, "The Effective Exchange Rates of the Euro," ECB Occasional Paper No. 2 (Frankfurt: ECB, February).

Cheung, Yin-Wong, 2003, “An Analysis of Hong Kong Export Performance,” Working Paper No. 09/2003 (HK: Hong Kong Institute for Monetary Research).

Cheung, Yin-Wong and Kon. S. Lai, 1993, "Finite-Sample Sizes of Johansen's Likelihood Ratio Tests for Cointegration," Oxford Bulletin of Economics and Statistics 55(3): 313-328

Chinn, Menzie, forthcoming, "Doomed to Deficits? Aggregate U.S. Trade Flows Revisited," Review of World Economics (Weltwirtschaftliches Archiv). Also NBER Working Paper No. 9521 (February 2003).

Chinn, Menzie, 2005, “How Far Has the Dollar Fallen?” La Follette School Working Paper No. 2005-003 (February).

Chinn, Menzie, 2004, "Incomes, Exchange Rates and the U.S. Trade Deficit, Once Again," International Finance 7(3) (Winter): 1-19. 
Chinn, Menzie, 2000a, "Before the Fall: Were East Asian Currencies Overvalued?" Emerging Markets Review 1(2) (August 2000): 101-126.

Chinn, Menzie, 2000b, "The Usual Suspects: Productivity and Demand Shocks and Asia-Pacific Real Exchange Rates," Review of International Economics 8(1): 20-43.

Chinn, Menzie, 1999, "Productivity, Government Spending and the Real Exchange Rate: Evidence for OECD Countries," in Equilibrium Exchange Rates, edited by Ronald MacDonald and Jerome Stein (Boston: Kluwer Academic Publishers), pp. 163-190.

Chinn, Menzie, Michael Dooley, and Sona Shrestha, 1999, "Latin America and East Asia in the Context of an Insurance Model of Currency Crises," Journal of International Money and Finance 18(4) (August 1999): 659-681.

Chinn, Menzie and Louis Johnston, 1999, “The Impact of Productivity Differentials on Real Exchange Rates: Beyond the Balassa-Samuelson Framework," Working Paper \#442 (Santa Cruz: Dept. of Economics, University of California, June).

Clark, Peter and Ronald MacDonald, 1999, "Exchange Rates and Economic Fundamentals: A Methodological Comparison of Beers and Feers," in J. Stein and R. MacDonald (eds.)

Equilibrium Exchange Rates (Kluwer: Boston), pp. 285-322.

Council of Economic Advisers, 2001, Economic Report of the President (Washington, D.C.: U.S. GPO, January).

Cromb, Roy, 1999, “An Effective Exchange Rate Index for the Euro Area," Quarterly Bulletin (London: Bank of England, May).

DeGregorio, Jose and Holger Wolf, 1994, "Terms of Trade, Productivity, and the Real Exchange Rate," NBER Working Paper \#4807 (July).

Edwards, Sebastian, 1989a, "Economic Liberalization and the Equilibrium Real Exchange Rate in Developing Countries," in Debt, Stabilization and Development: Essays in Memory of Carlos F. Diaz-Alejandro, G. Calvo, et al. (Eds.) (Oxford: Basil Blackwell), pp. 163-84.

Edwards, Sebastian, 1989b, Real Exchange Rates, Devaluation and Adjustment: Exchange Rate Policy in Developing Countries (Cambridge, Mass.: MIT Press).

Ellis, Luci, 2001, "Measuring the Real Exchange Rate: Pitfalls and Practicalities," Reserve Bank of Australia Research Discussion Paper 2001-04 (August).

Engel, Charles, 1999, “Accounting for US Real Exchange Rate Changes,” Journal of Political Economy 107(3):507-538 
European Commission, 2002, "Price and Cost Competitiveness: Technical Appendix," (Brussels: Directorate-General for Economic and Financial Affairs).

Frankel, Jeffrey and Andrew Rose, 1996, "Currency Crashes in Emerging Markets: An Empirical Treatment,” Journal of International Economics 41(3/4): 351-368.

Fukuda, Shin-ichi, and Takashi Kano, 1997, "International Price Linkage within a Region:

The Case of East Asia," Journal of the Japanese and International Economies 11: 643-666.

Goldfajn, Ilan and Rodrigo Valdes, 1999, "The Aftermath of Appreciations," Quarterly Journal of Economics 114(1): 229-262.

Goldstein, Morris and Mohsin Khan, 1985, "Income and Price Effects in Foreign Trade," in R. Jones and P. Kenen (eds.), Handbook of International Economics, Vol. 2, (Amsterdam: Elsevier), Chapter 20.

Golub, Stephen, 1994, Comparative Advantage, Exchange Rates and Sectoral Trade Balances of Major Industrial Countries," IMF Staff Papers 41(2) (June): 286-313.

Hargreaves, Derek, and Carlton Strong, 2003, "JPMorgan effective exchange rates: revised and modernized," Economic Research note (New York: J.P. Morgan Chase Bank, May).

Hinkle, Lawrence E. and Peter J. Montiel (eds.), Exchange Rate Misalignment (Oxford University Press/World Bank.

Hinkle, Lawrence E. and Fabien Nsengiyumva, 1999, "External Real Exchange Rates: Purchasing Power Parity, the Mundell-Fleming Model, and Competitiveness in Traded Goods," Chapter 2 in Hinkle, Lawrence E. and Peter J. Montiel (eds.), Exchange Rate Misalignment (Oxford University Press/World Bank), pp. 41-104.

Horvath, Michael and Mark Watson, 1995, "Testing for Cointegration when Some of the Cointegrating Vectors Are Prespecified," Econometric Theory 11: 984-1014.

Hsieh, David, 1982, "The Determination of the Real Exchange Rate: The Productivity Approach," Journal of International Economics 12(2): 355-362.

Isard, Peter and Steven Symansky, 1996, "Long Run Movements in Real Exchange Rates," Chapter 2 in Takatoshi Ito, Peter Isard, Steven Symansky and Tamim Bayoumi, Exchange Rate Movements and Their Impact on Trade and Investment in the APEC Region, Occasional Paper 145 (Washington, DC: International Monetary Fund, December).

Ito, Takatoshi, Eiji Ogawa and Yuri Nagataki Sasaki, 1998, "How Did the Dollar Peg Fail in Asia?” NBER Working Paper \#6729 (September). 
Johansen, Søren, 1988, "Statistical Analysis of Cointegrating Vectors," Journal of Economic Dynamics and Control 12: 231-54.

Johansen, Søren, and Katerina Juselius, 1990, "Maximum Likelihood Estimation and Inference on Cointegration - With Applications to the Demand for Money," Oxford Bulletin of Economics and Statistics 52: 169-210.

Johnston, Louis D. and Menzie Chinn, 1996, "How Well Is America Competing? A Comment on Papadakis," Journal of Policy Analysis and Management 15(1) (Winter): 68-81.

Kaminsky, Graciela L and Carmen M. Reinhart, 1999, "The Twin Crises: The Causes of Banking and Balance-of-Payments Problems," American Economic Review 89(3): 473-500.

Lawrence, Robert Z., 1990, "U.S. Current Account Adjustment: An Appraisal," Brookings Papers on Economic Activity No. 2: 343-382.

Lee, Daniel Y., 1999, "Purchasing Power Parity and Dynamic Error Correction: Evidence from Asia Pacific Economies," International Review of Economics and Finance 8(2).

Loretan, Mico, 2005, "Indexes of the foreign exchange value of the dollar," Federal Reserve Bulletin (Winter): 1-8.

Maciejewski, Edouard, 1983, "'Real' Effective Exchange Rate Indices: A Re-Examination of the Major Conceptual and Methodological Issues," IMF Staff Papers 30(3) (September): 491-541.

Maeso-Fernandez, Francisco, Chiara Osbat and Bernd Schnatz, 2002, "Determinants of the euro real effective exchange rate: a BEER/PEER approach," Australian Economic Papers 41(4): 437461. Also ECB Working Paper No. 85 (Frankfurt: ECB, November 2001).

Marsh, Ian and Stephen Tokarick, 1996, "An Assessment of Three Measures of Competitiveness," Weltwirtschaftliches Archiv 132(4): 700-722.

Meade, Ellen, 1991, "Computers and the Trade Deficit: the case of the falling prices" in P. Hooper and D. Richardson, (eds.) International Economic Transactions: Issues in Measurement and Empirical Research, NBER Studies in Income and Wealth vol. 55.

Ogawa, Eiji, 2000, "On the Desirability of a Regional Basket Currency Arrangement," NBER Working Paper 8002 (November).

Parsley, David, 2001, "Accounting for Real Exchange Rate Changes in East Asia," Hong Kong Institute of Monetary Research Working Paper No. 6/2001 (July).

Phylaktis, Kate and Yiannis Kassimatis, 1994, "Does the Real Exchange Rate Follow a Random Walk? The Pacific Basin Perspective," Journal of International Money \& Finance 13(4): 476-495. 
Rogoff, Kenneth, 1996, "The Purchasing Power Parity Puzzle," Journal of Economic Literature 34(2): 647-668.

Rose, Andrew, 1991, "The Role of Exchange Rates in a Popular Model of International Trade: Does the 'Marshall-Lerner' Condition Hold?’ Journal of International Economics 31: 301-316.

Sachs, Jeffrey, Aaron Tornell and Andres Velasco, 1996, "Financial Crises in Emerging Markets: The Lessons from 1995," Brookings Papers on Economic Activity 1996 (1): 147-215.

Salter, Wilfred A., 1959, "Internal and External Balance: The Role of Price and Expenditure Effects," Economic Record 35: 226-38.

Samuelson, Paul, 1964, "Theoretical Notes on Trade Problems," Review of Economics and Statistics 46: 145-154.

Spencer, Michael and Aileen Wong, 2002, "Asian Export Competitiveness and the Yen," Mimeo, Global Markets Research, Deutsche Bank (February 25).

Spilimbergo, Antonio and Athanasios Vamvakidis, 2003, "Real Effective Exchange Rate and the Constant Elasticity of Substitution Assumption," Journal of International Economics 60(2): 337354.

Swan, Trevor, 1960, "Economic Control in a Dependent Economy," Economic Record 36: 5166.

Turner, Anthony and Toshitaka Sekine, 1999, "Effective Exchange Rate Data for Euro Area to Be Published in International Financial Statistics," IMF Survey 28(8) (April 26): 123.

Williamson, John (editor), Estimating Equilibrium Exchange Rates (Washington, DC: Inst. International Economics).

Zanello, Allesandro, and Dominique Desruelle, 1997, “A Primer on IMF's Information Notices System,” Working Paper WP97/71 (Washington, DC: International Monetary Fund). 


\section{Appendix 1: Data Appendix}

IF S denotes IMF, International Financial Statistics, February 2002 CD-ROM updated using the IMF's Economic Data Sharing System (EDSS) in February 2002; and July 2002 CD-ROM.

- Exchange rates, IFS line ae, in US\$/local currency unit, end of period.

- Consumer price index, IFS line 64, $1990=100$. Hong Kong CPI data is seasonally adjusted, and obtained from the EDSS.

- Producer price index, IFS line 63, 1990 = 100 .

- Export price index, IFS line 74, 1990= 100.

- Trade-weighted real exchange rates (CPI-deflated). 1990=100, 1988-1990 trade weights. Source: IMF Information Notice System.

- Trade-weighted real exchange rates (unit labor cost-deflated). 1990=100, 19881990 trade weights, IFS line reu.

- "Broad" trade-weighted real exchange rates (PPI-deflated). 1990=100, 1990 trade weights for 1987-2001; 1980 trade weights for 1970-86 (weights exclude China). Hong Kong series adjusted by Hong Kong retail price index Source: J.P. Morgan, http://www.jpmorgan.com. For a description of the series construction, see Hargreaves and Strong (2003).

- US "Major" trade weighted exchange rate (CPI deflated). Federal Reserve Board website, http://www.federalreserve.gov/releases/h10/Summary/indexnc_m.txt. Weights are listed at http://www.federalreserve.gov/releases/h10/Weights/.

- Deutsche Bank East Asian real effective exchange rate indices. Personal communication with Aileen Wong, Deutsche Bank Asia Pacific Equity Markets.

- Euro trade weighted exchange rates. ECB website, http://www.ecb.int/stats/mb/eastats.htm\#download.

Data for Section 4.3 mainly drawn from Bureau of Economic Analysis, and described in Chinn (2002). 
Appendix 2: Trade Weighted Indices

Table A1: Details of Selected Indices

\begin{tabular}{|l|l|l|l|l|}
\hline & Deflator & $\begin{array}{l}\text { Trade } \\
\text { weights }\end{array}$ & Index type & Comments \\
\hline IMF rec & $\begin{array}{l}\text { CPI , HP } \\
\text { filtered }\end{array}$ & $\begin{array}{l}\text { Allows for } \\
\text { third market } \\
\text { competition }\end{array}$ & $\begin{array}{l}\text { Fixed base } \\
\text { year weights }\end{array}$ & \\
\hline IMF reu & $\begin{array}{l}\text { Unit labor } \\
\text { cost }, \mathrm{HP} \\
\text { filtered }\end{array}$ & $\begin{array}{l}\text { Allows for } \\
\text { third market } \\
\text { competition }\end{array}$ & $\begin{array}{l}\text { Fixed base } \\
\text { year weights }\end{array}$ & $\begin{array}{l}\text { Only available for } \\
\text { selected } \\
\text { industrialized } \\
\text { countries }\end{array}$ \\
\hline $\begin{array}{l}\text { JP Morgan } \\
\text { "narrow" }\end{array}$ & PPI & $\begin{array}{l}\text { Bilateral, for } \\
\text { OECD } \\
\text { countries }\end{array}$ & $\begin{array}{l}\text { Fixed base } \\
\text { year weights }\end{array}$ & $\begin{array}{l}\text { Only available for } \\
\text { OECD countries }\end{array}$ \\
\hline $\begin{array}{l}\text { JP Morgan } \\
\text { "broad" }\end{array}$ & PPI & $\begin{array}{l}\text { For OECD } \\
\text { and } \\
\text { emerging } \\
\text { markets }\end{array}$ & $\begin{array}{l}\text { Fixed base } \\
\text { year weights } \\
\text { (post-2003 } \\
\text { series include } \\
\text { China weights) }\end{array}$ & $\begin{array}{l}\text { Available for OECD } \\
\text { countries and } \\
\text { emerging markets. }\end{array}$ \\
\hline FRB "major" & CPI & $\begin{array}{l}\text { For major } \\
\text { trading } \\
\text { partners }\end{array}$ & $\begin{array}{l}\text { Chain } \\
\text { weighting }\end{array}$ & United States \\
\hline FRB "broad" & CPI & $\begin{array}{l}\text { For broad } \\
\text { set of } \\
\text { trading } \\
\text { partners }\end{array}$ & $\begin{array}{l}\text { Chain } \\
\text { weighting }\end{array}$ & United States \\
\hline FRB Atlanta & CPI & $\begin{array}{l}\text { For broad } \\
\text { set of } \\
\text { trading } \\
\text { partners }\end{array}$ & $\begin{array}{l}\text { Intermittent } \\
\text { updating }\end{array}$ & United States \\
\hline DeutscheBank & PPI & $\begin{array}{l}\text { Allows for } \\
\text { third country } \\
\text { compeition }\end{array}$ & $\begin{array}{l}\text { Fixed base } \\
\text { year weights }\end{array}$ & $\begin{array}{l}\text { East Asian } \\
\text { countries }\end{array}$ \\
\hline
\end{tabular}

Source: Zanello and Desruelle (1997), Loretan (2005), Hargreaves and Strong (2003), Acree (1999), Spencer and Wong (2002). 
Table A2: Details of Euro Effective Exchange Rate Indices

\begin{tabular}{|l|l|l|l|l|}
\hline & Deflator & $\begin{array}{l}\text { Trade } \\
\text { weights }\end{array}$ & Index type & Comments \\
\hline IMF rec & $\begin{array}{l}\text { CPI , HP } \\
\text { filtered }\end{array}$ & $\begin{array}{l}\text { Allows for } \\
\text { third market } \\
\text { competition }\end{array}$ & $\begin{array}{l}\text { Fixed base } \\
\text { year weights }\end{array}$ & $\begin{array}{l}\text { Covers almost all } \\
\text { IMF members }\end{array}$ \\
\hline IMF reu & $\begin{array}{l}\text { Unit labor } \\
\text { cost , HP } \\
\text { filtered }\end{array}$ & $\begin{array}{l}\text { Allows for } \\
\text { third market } \\
\text { competition }\end{array}$ & $\begin{array}{l}\text { Fixed base } \\
\text { year weights }\end{array}$ & $\begin{array}{l}\text { Covers 21 } \\
\text { industrialized } \\
\text { countries }\end{array}$ \\
\hline BIS & CPI & $\begin{array}{l}\text { Allows for } \\
\text { third market } \\
\text { competition }\end{array}$ & $\begin{array}{l}\text { Fixed base } \\
\text { year weights } \\
\text { (1989-91) }\end{array}$ & \\
\hline ECB "broad" & CPI & $\begin{array}{l}\text { Allows for } \\
\text { third market } \\
\text { competition }\end{array}$ & $\begin{array}{l}\text { Fixed base } \\
\text { year weights } \\
(1995-97)\end{array}$ & $\begin{array}{l}\text { Covers 38 trading } \\
\text { partners }\end{array}$ \\
\hline ECB "narrow" & CPI, PPI & $\begin{array}{l}\text { Allows for } \\
\text { third market } \\
\text { competition }\end{array}$ & $\begin{array}{l}\text { Fixed base } \\
\text { year weights } \\
(1995-97)\end{array}$ & $\begin{array}{l}\text { Covers 12 major } \\
\text { trading partners }\end{array}$ \\
\hline $\begin{array}{l}\text { European } \\
\text { Commission } \\
\text { (ECFIN) }\end{array}$ & $\begin{array}{l}\text { GDP } \\
\text { deflator, unit } \\
\text { labor cost } \\
\text { (economy or } \\
\text { mfg.) }\end{array}$ & $\begin{array}{l}\text { Allows for } \\
\text { third market } \\
\text { competition }\end{array}$ & $\begin{array}{l}\text { Moving } \\
\text { weights }\end{array}$ & $\begin{array}{l}\text { Covers 12 non- } \\
\text { euro industrial } \\
\text { countries (incl. 3 } \\
\text { market effects) plus } \\
\text { other regions }\end{array}$ \\
\hline & & & & \\
\hline
\end{tabular}

Source: Zanello and Desruelle (1997), Turner and Sekine (1999), Cromb (1999),

Buldoroni, Makrydakis and Thimann (2002) and European Commission (2002). 
Table 1

Horvath-Watson Test Results for US\$, ¥ and Trade-Weighted Exchange Rates

1975.01-1996.12

Panel 1.1: CPI

\begin{tabular}{|c|c|c|c|c|c|c|c|c|c|c|}
\hline & & $\mathrm{HK}$ & IN & JP & $\mathrm{KO}$ & MA & $\mathrm{PH}$ & SI & $\mathrm{TH}$ & $\mathrm{TA}$ \\
\hline US\$ & $\begin{array}{l}\mathrm{k} \\
\mathrm{W}\end{array}$ & $\begin{array}{l}12 \\
11.549 * \star\end{array}$ & $\begin{array}{l}1 \\
17.913 * \star \star\end{array}$ & $\begin{array}{c}12 \\
4.484\end{array}$ & $\begin{array}{l}12 \\
14.323 * * *\end{array}$ & $\begin{array}{l}11 \\
5.121\end{array}$ & $\begin{array}{l}11 \\
1.456\end{array}$ & $\begin{array}{l}12 \\
2.277\end{array}$ & $\begin{array}{l}1 \\
18.523 * \star *\end{array}$ & $\begin{array}{l}1 \\
10.544 \text { * }\end{array}$ \\
\hline$¥$ & $\begin{array}{l}\mathrm{k} \\
\mathrm{W}\end{array}$ & $\begin{array}{l}1 \\
8.773\end{array}$ & $\begin{array}{l}12 \\
9.309+\end{array}$ & $\begin{array}{l}-- \\
--\end{array}$ & $\begin{array}{l}12 \\
13.005 * \star\end{array}$ & $\begin{array}{l}12 \\
4.104\end{array}$ & $\begin{array}{l}12 \\
8.674\end{array}$ & $\begin{array}{l}12 \\
6.202\end{array}$ & $\begin{array}{l}12 \\
4.936\end{array}$ & $\begin{array}{l}12 \\
16.914 * \star \star\end{array}$ \\
\hline TWXR & $\begin{array}{l}\mathrm{k} \\
\mathrm{W}\end{array}$ & $\begin{array}{l}1 \\
7.414\end{array}$ & $\begin{array}{l}1 \\
4.569\end{array}$ & $\begin{array}{l}1 \\
8.372\end{array}$ & $\begin{array}{l}1 \\
4.059\end{array}$ & $\begin{array}{l}1 \\
1.322\end{array}$ & $\begin{array}{l}1 \\
2.356\end{array}$ & $\begin{array}{l}1 \\
2.061\end{array}$ & $\begin{array}{l}1 \\
1.408\end{array}$ & $\begin{array}{l}1 \\
9.198+\end{array}$ \\
\hline
\end{tabular}

Panel 1.2: PPI

\begin{tabular}{|c|c|c|c|c|c|c|c|c|c|c|}
\hline \multirow[t]{2}{*}{ US\$ } & $\mathrm{k}$ & -- & 1 & 12 & 12 & 2 & 12 & 12 & 5 & 4 \\
\hline & W & -- & 10.544 * & 3.497 & $13.742 * *$ & 2.649 & 4.036 & 7.095 & $12.050 * *$ & 4.368 \\
\hline \multirow[t]{2}{*}{$¥$} & $\mathrm{k}$ & -- & 12 & -- & 11 & 1 & 2 & 3 & 2 & 6 \\
\hline & W & -- & 4.640 & -- & 3.465 & $12.413 * \star$ & $9.867 *$ & 2.919 & 7.346 & 2.267 \\
\hline \multirow[t]{2}{*}{ TWXR } & $\mathrm{k}$ & 1 & 1 & 1 & 1 & 1 & 1 & 1 & 1 & 1 \\
\hline & $\mathrm{W}$ & $10.098 *$ & 2.990 & 7.066 & 5.918 & $10.318 *$ & 8.674 & 0.111 & 1.403 & 1.835 \\
\hline
\end{tabular}

Panel 1.3: Export Price Indices

\begin{tabular}{|c|c|c|c|c|c|c|c|c|c|c|}
\hline \multirow[t]{2}{*}{ US\$ } & $\mathrm{k}$ & 12 & 11 & 12 & 1 & 4 & 12 & 1 & 1 & -- \\
\hline & W & $9.630+$ & 5.366 & 3.926 & 3.926 & 7.690 & 8.374 & 3.337 & $22.270 * \star \star *$ & -- \\
\hline \multirow[t]{2}{*}{$¥$} & $\mathrm{k}$ & 1 & 11 & -- & 1 & 1 & 2 & 2 & 1 & -- \\
\hline & W & 6.198 & 3.838 & -- & 5.110 & 0.762 & 4.705 & 3.323 & 2.644 & -- \\
\hline
\end{tabular}

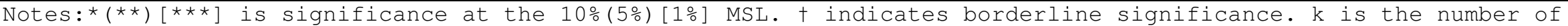

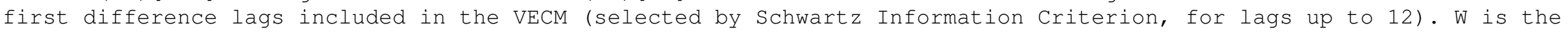

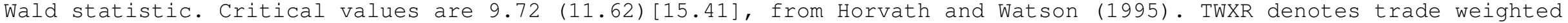
exchange rate (PPI deflated series from Morgan Guaranty, CPI deflated series from IMF). Source: Chinn (2000a). 
Table 2

U.S. Exports Equation

1975q1-2003q2

\begin{tabular}{|c|c|c|c|c|}
\hline $\begin{array}{l}\text { Long Run } \\
\text { Coeff }\end{array}$ & Pred & $\begin{array}{l}\text { CPI defl. } \\
{[1]}\end{array}$ & $\begin{array}{l}\text { PPI defl. } \\
{[2]}\end{array}$ & $\begin{array}{l}\text { ULC defl. } \\
{[3]}\end{array}$ \\
\hline $\begin{array}{l}C \cdot V \cdot[a s y \cdot] \\
C \cdot V \cdot[f . s .]\end{array}$ & & $\begin{array}{l}2,2 \\
2,1\end{array}$ & 1,1 & 1,1 \\
\hline q & $(+)$ & $\begin{array}{l}2.281 * \\
(0.596)\end{array}$ & $\begin{array}{l}1.949 * \\
(0.622)\end{array}$ & $\begin{array}{l}0.726 * \star \\
(0.090)\end{array}$ \\
\hline $\mathrm{Y}$ & $(+)$ & $\begin{array}{l}1.695 \\
(0.233)\end{array}$ & $\begin{array}{l}1.987 \\
(0.205)\end{array}$ & $\begin{array}{l}1.615 * \\
(0.053)\end{array}$ \\
\hline $\begin{array}{l}\operatorname{lag} \\
\mathrm{N}\end{array}$ & & $\begin{array}{l}2 \\
114\end{array}$ & $\begin{array}{l}2 \\
114\end{array}$ & $\begin{array}{l}2 \\
114\end{array}$ \\
\hline
\end{tabular}

$\begin{array}{lllll}\operatorname{Ex} & (-) & -0.011 * \star \star & -0.009 & -0.168 * \star \star \\ & (0.005) & (0.006) & (0.030) \\ & (-) & 0.008 & 0.007 & -0.052 \\ & (0.006) & (0.006) & (0.048) \\ & (+) & (0.000) & (0.000) & (0.001)\end{array}$

Notes: "Coeff" is the coefficient from equation (A2) (standard errors in parentheses). "Pred" indicates predicted sign. "C.V." indicates the number of cointegrating vectors identified using the trace, maximal eigenvalue statistics, and the $1 \%$ significance level; [asy.] indicates asymptotic critical values, while [f.s.] indicates use of finite sample critical values (Cheung and Lai, 1993). Coefficients are long run parameter estimates from the Johansen procedure described in the text. Lag is the number of lags in the VAR specification of the system. $\mathrm{N}$ is the effective number of observations included in the regression. $*(* *)[* * *]$ denotes significance at the $10 \%(5 \%)[1 \%]$ level, using a likelihood ratio test for the relevant zero restriction. Source: Chinn (2004), Table 1. 
Table 3

U.S. Imports Equation

1975q1-2003q2

\begin{tabular}{|c|c|c|c|c|c|}
\hline $\begin{array}{l}\text { Long Run } \\
\text { Coeff }\end{array}$ & Pred & $\begin{array}{l}\text { CPI defl. } \\
\text { Imports } \\
{[1]}\end{array}$ & $\begin{array}{l}\text { PPI defl. } \\
\text { Imports } \\
\text { [2] }\end{array}$ & $\begin{array}{l}\text { ULC defl. } \\
\text { Imports } \\
\text { [3] }\end{array}$ & $\begin{array}{l}\text { PPI defl. } \\
\text { Imports ex. } \\
\text { Comp. } \\
{[4]}\end{array}$ \\
\hline $\begin{array}{l}\text { C.V. [asy.] } \\
C \cdot V \cdot[f . s \cdot]\end{array}$ & & $\begin{array}{l}1,1 \\
1,1\end{array}$ & $\begin{array}{l}1,1 \\
1,1\end{array}$ & $\begin{array}{l}1,1 \\
0,1\end{array}$ & $\begin{array}{l}1,1 \\
1,1\end{array}$ \\
\hline q & $(-)$ & $\begin{array}{l}-0.211 \\
(0.150)\end{array}$ & $\begin{array}{l}-0.115 \\
(0.230)\end{array}$ & $\begin{array}{l}-0.137 \\
(0.143)\end{array}$ & $\begin{array}{l}-0.308+ \\
(0.162)\end{array}$ \\
\hline y & $(+)$ & $\begin{array}{l}2.287 \star \star \star \\
(0.069)\end{array}$ & $\begin{array}{l}2.293 * * * \\
(0.085)\end{array}$ & $\begin{array}{l}2.234 * \star \star \\
(0.092)\end{array}$ & $\begin{array}{l}2.002 * \star * \\
(0.057)\end{array}$ \\
\hline $\begin{array}{l}\operatorname{lag} \\
\mathrm{N}\end{array}$ & & $\begin{array}{l}2 \\
114\end{array}$ & $\begin{array}{l}2 \\
114\end{array}$ & $\begin{array}{l}2 \\
114\end{array}$ & $\begin{array}{l}4 \\
114\end{array}$ \\
\hline \multicolumn{6}{|c|}{ Error correction coefficients } \\
\hline $\operatorname{Im}$ & $(-)$ & $\begin{array}{l}-0.026 \\
(0.020)\end{array}$ & $\begin{array}{l}-0.020 \\
(0.017)\end{array}$ & $\begin{array}{l}0.022 \\
(0.019)\end{array}$ & $\begin{array}{l}-0.075^{\star \star} \\
(0.026)\end{array}$ \\
\hline q & $(+)$ & $\begin{array}{l}0.005 \\
(0.023)\end{array}$ & $\begin{array}{l}-0.001 \\
(0.015)\end{array}$ & $\begin{array}{l}-0.007 \\
(0.023)\end{array}$ & $\begin{array}{l}-0.006 \\
(0.025)\end{array}$ \\
\hline y & $(+)$ & $\begin{array}{l}0.031 * * * \\
(0.006)\end{array}$ & $\begin{array}{l}0.027 * * * \\
(0.005)\end{array}$ & $\begin{array}{l}0.029 * * * \\
(0.006)\end{array}$ & $\begin{array}{l}0.030 * * * \\
(0.008)\end{array}$ \\
\hline
\end{tabular}

Notes: "Coeff" is the coefficient from equation (A1) (standard errors in parentheses). "Pred" indicates predicted sign. "C.V." indicates the number of cointegrating vectors identified using the trace, maximal eigenvalue statistics, and the $1 \%$ significance level; [asy.] indicates asymptotic critical values, while [f.s.] indicates use of finite sample critical values (Cheung and Lai, 1993). Coefficients are long run parameter estimates from the Johansen procedure described in the text. Lag is the number of lags in the VAR specification of the system. $\mathrm{N}$ is the effective number of observations included in the regression. ${ }^{*}(*)[* * *]$ denotes significance at the $10 \%(5 \%)[1 \%]$ level, using a likelihood ratio test for the relevant zero restriction. Source: Chinn (2004), Table 2.

$\dagger$ Significant at $12 \%$ level. 


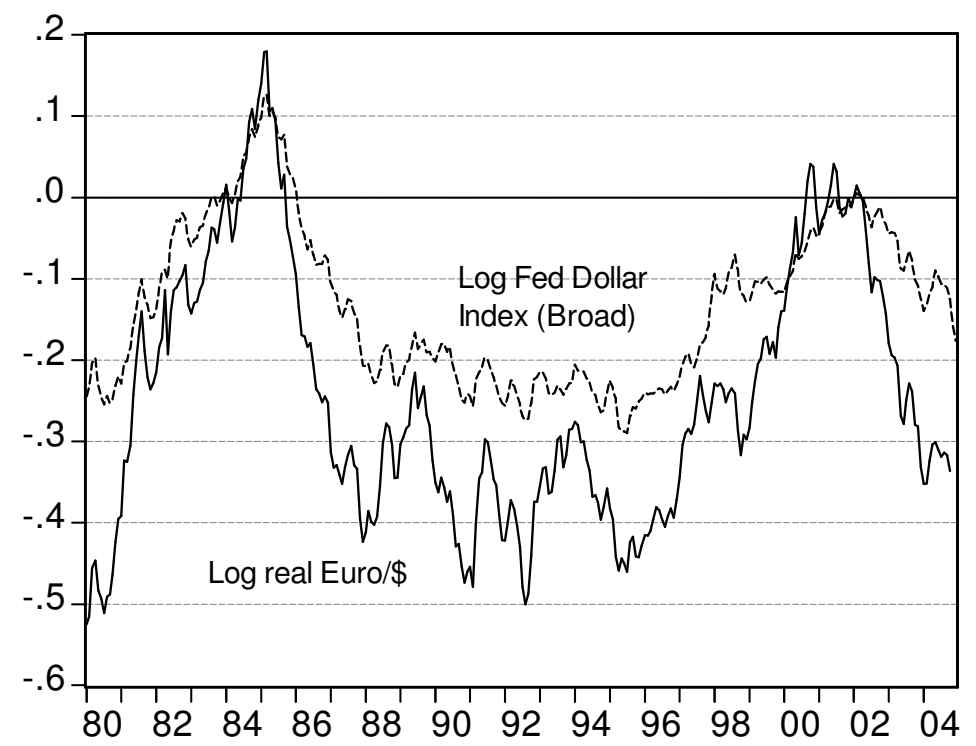

Figure 1: Log real value of dollar against euro, against broad basket,

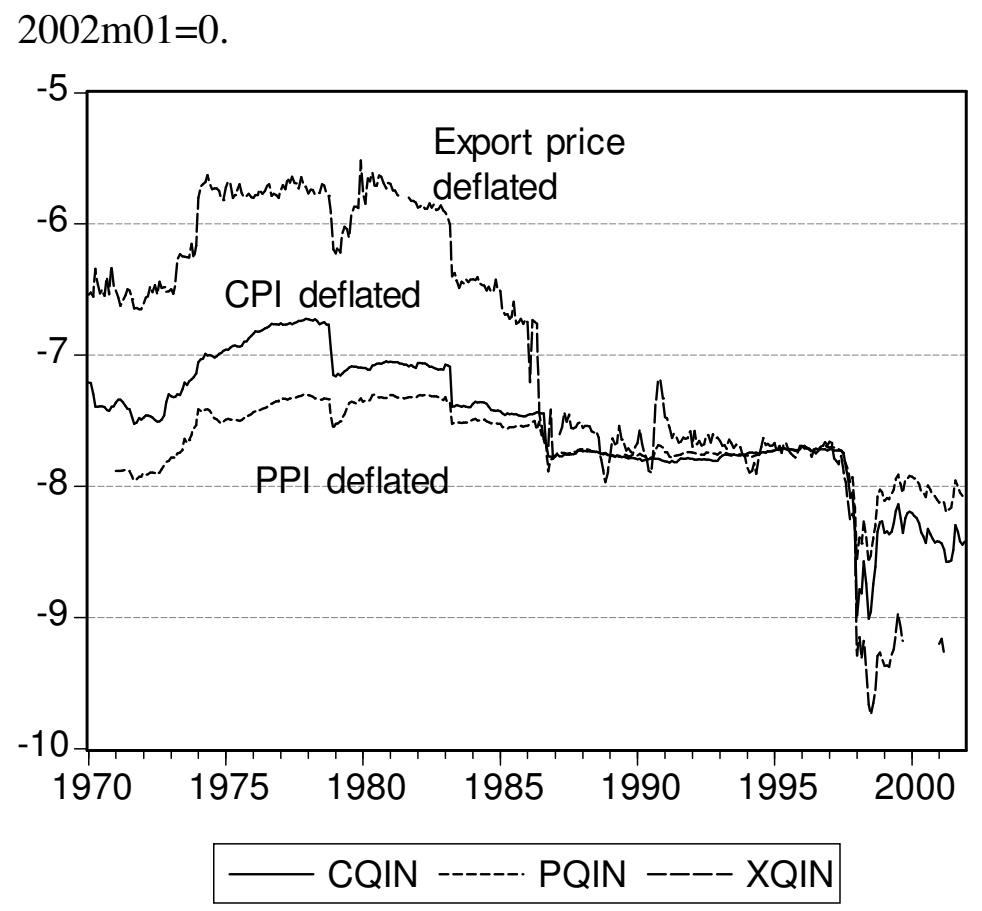

Figure 2: Indonesian Rupiah/US\$ Real Exchange Rates 


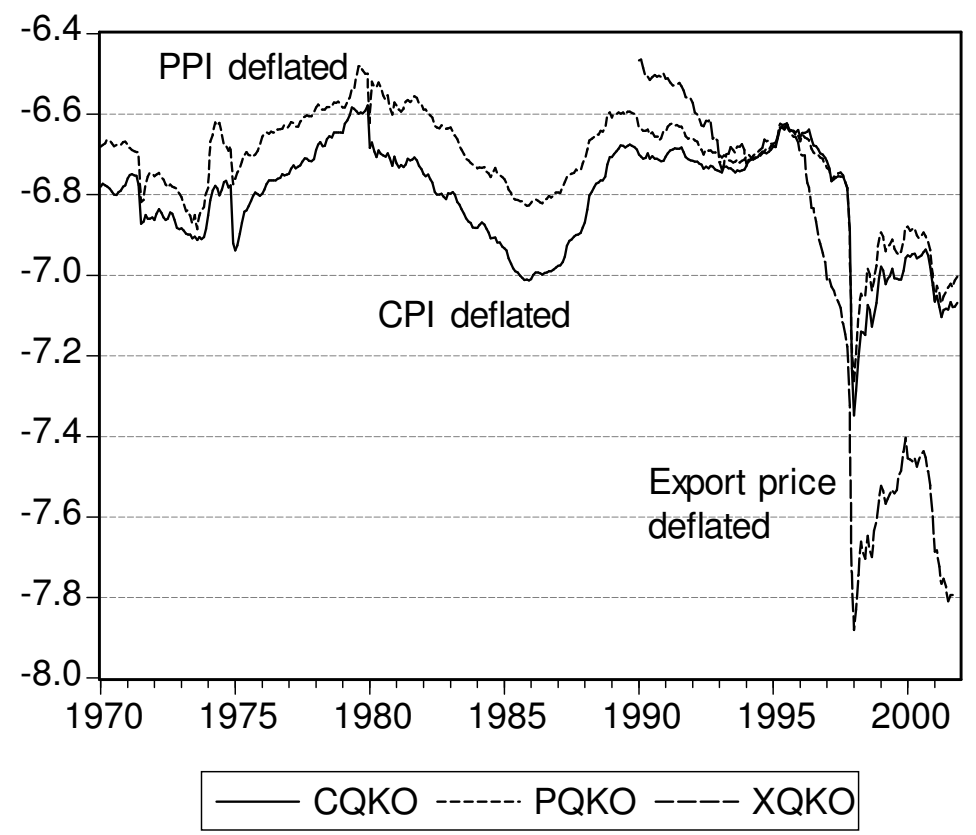

Figure 3: Korean Won/US\$ Real Exchange Rates

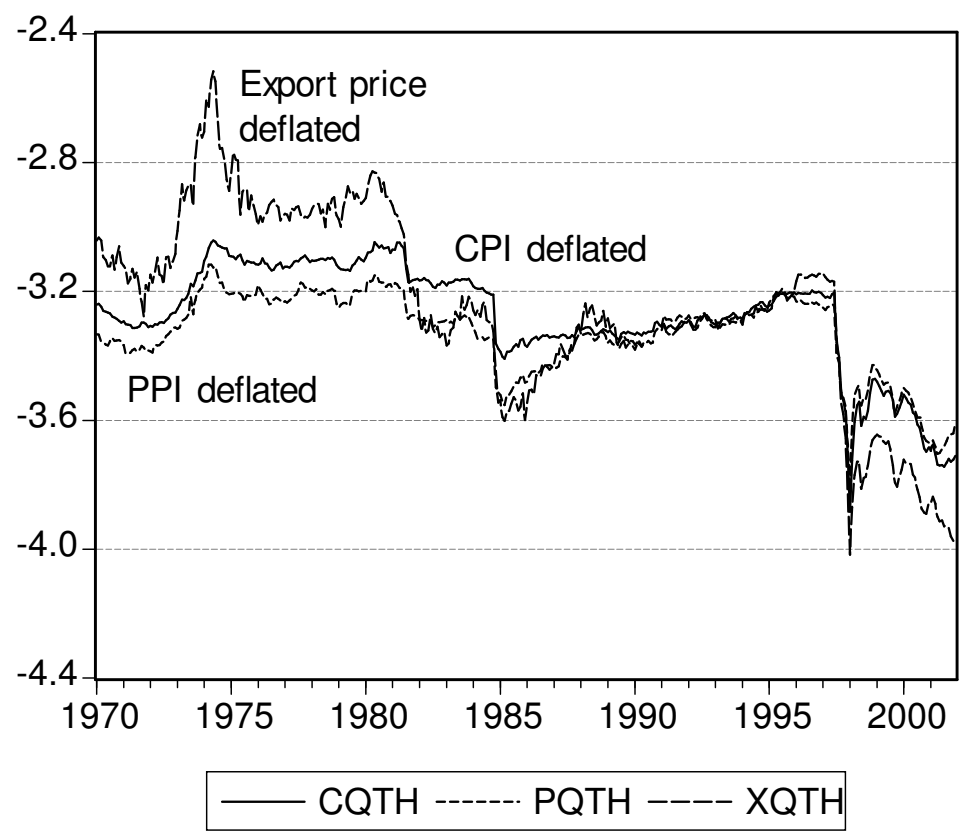

Figure 4: Thai Baht/US\$ Real Exchange Rates 


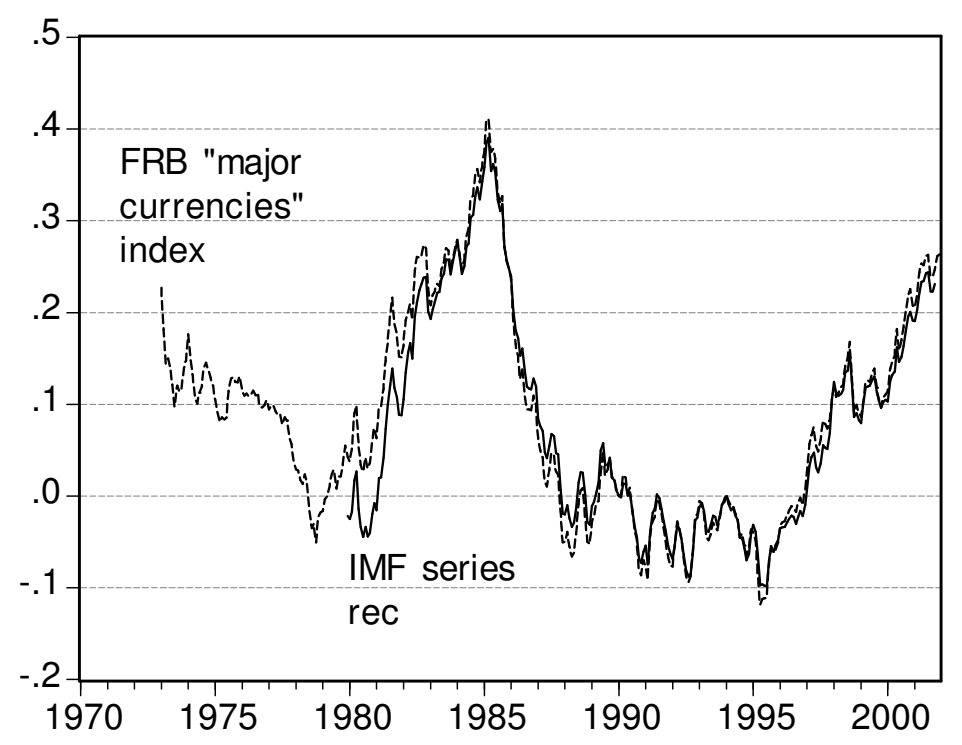

Figure 5: US\$ CPI-Deflated Exchange Rate Indices

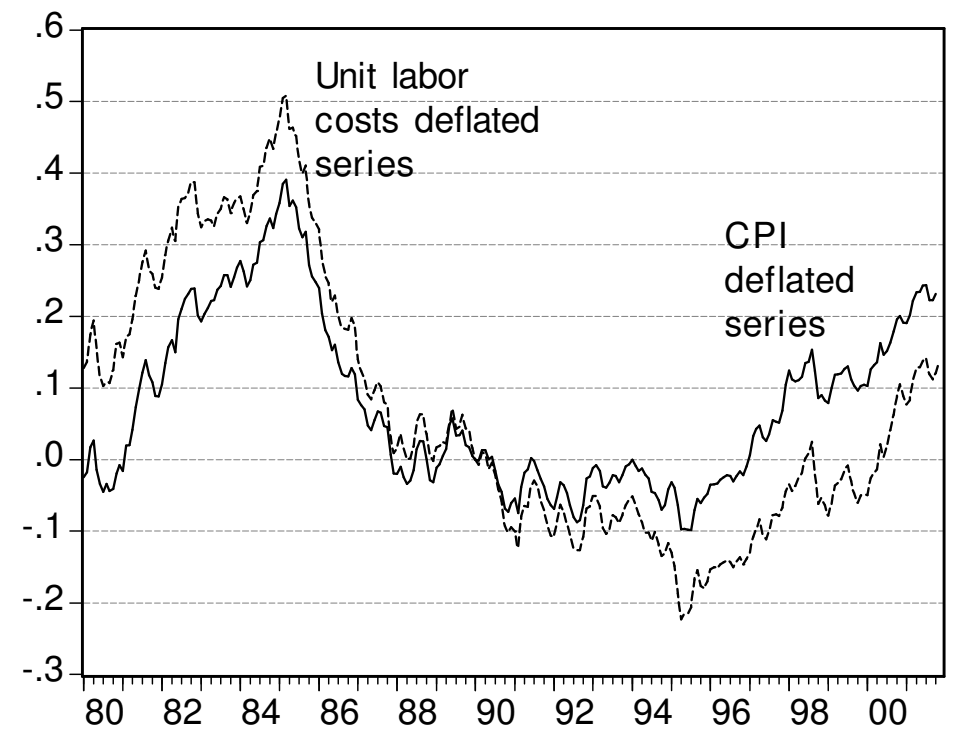

Figure 6: US\$ CPI and ULC Deflated Exchange Rate Indices 


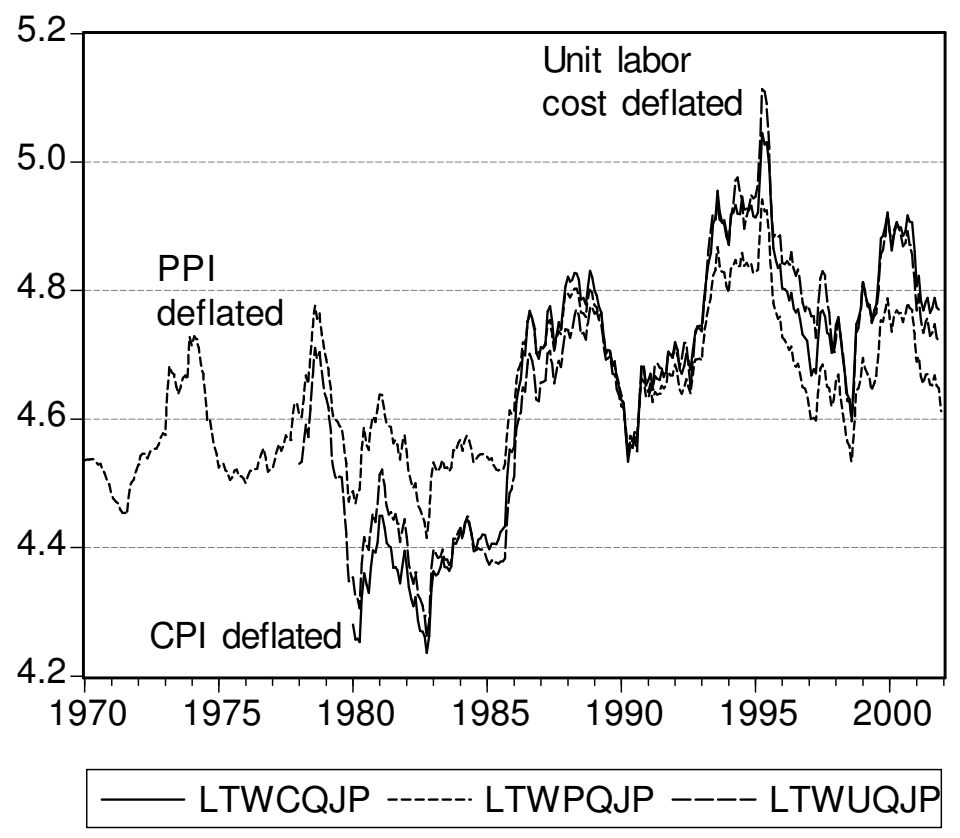

Figure 7: Japanese Yen CPI, PPI, ULC Deflated Indices

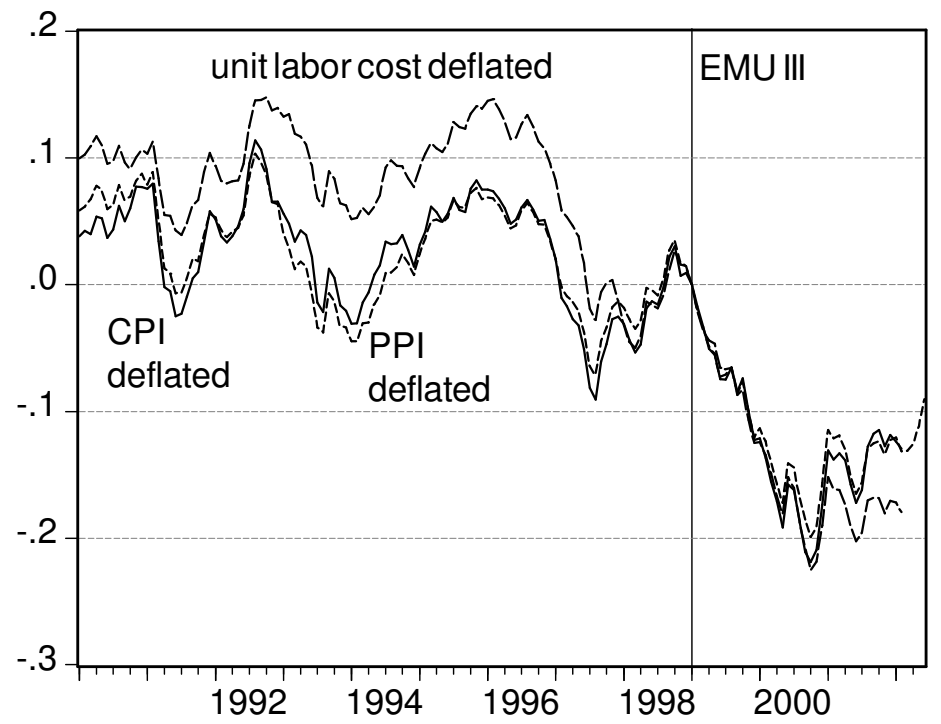

LTWCQEU-@ELEM(LTWCQEU,1999.01) LTWPQEU_ECB-@ELEM(LTWPQEU_ECB,1999.01) LTWUQEU-@ELEM(LTWUQEU,1999.01)

Figure 8: Euro CPI, PPI, ULC Deflated Indices 


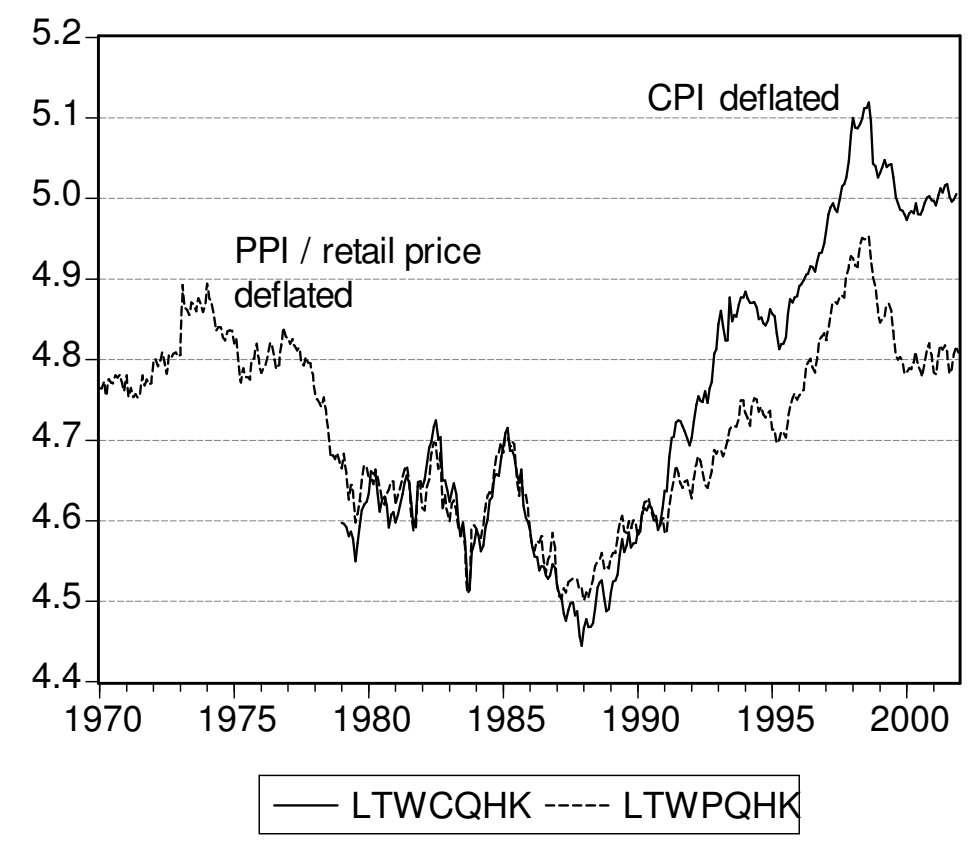

Figure 9: Hong Kong \$ CPI and PPI Deflated Indices

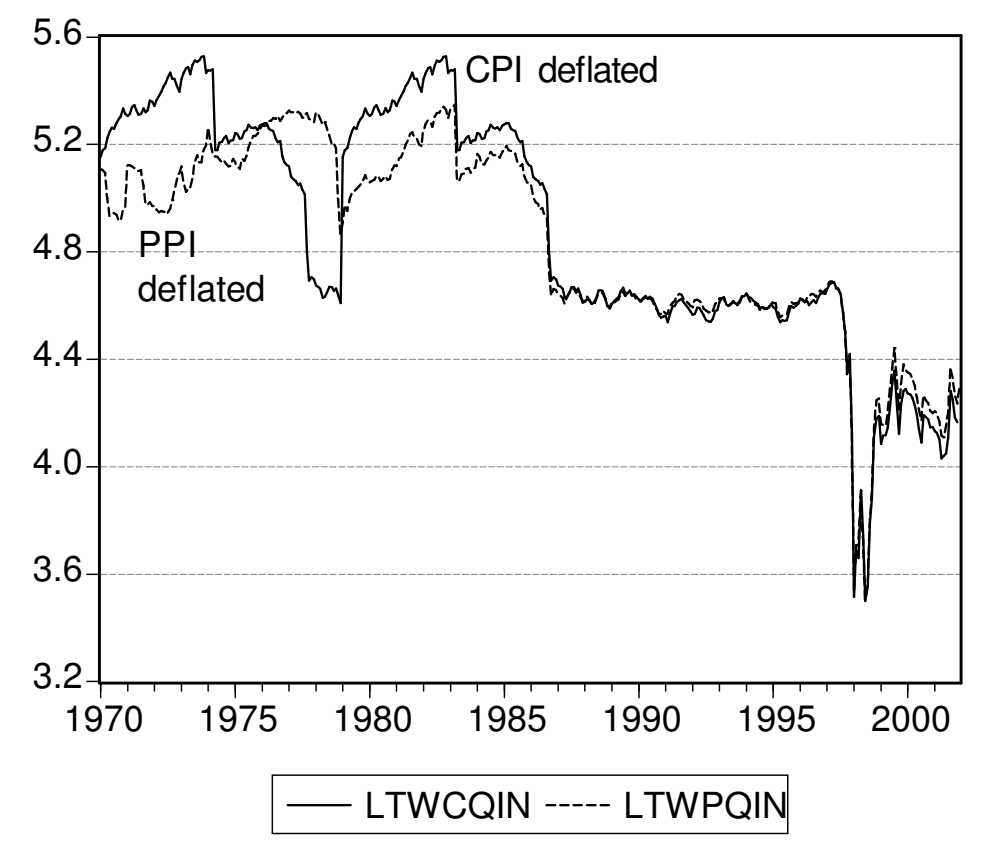

Figure 10: Indonesian Rupiah CPI and PPI Deflated Indices 


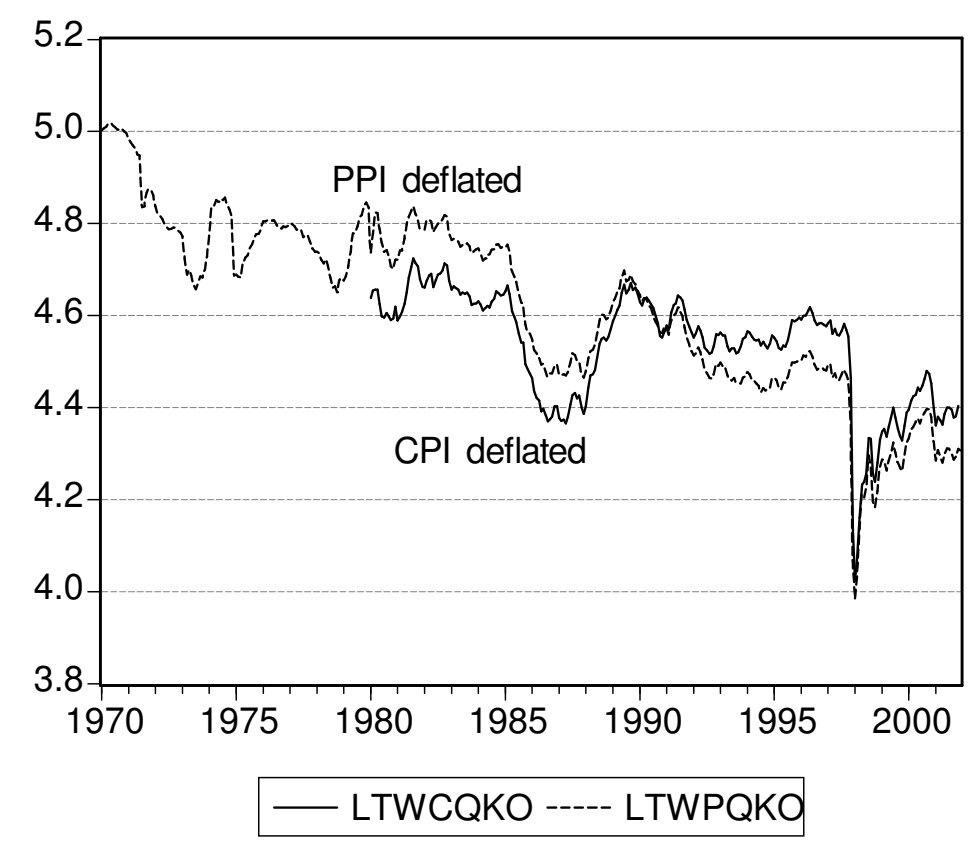

Figure 11: Korean Won CPI and PPI Deflated Indices

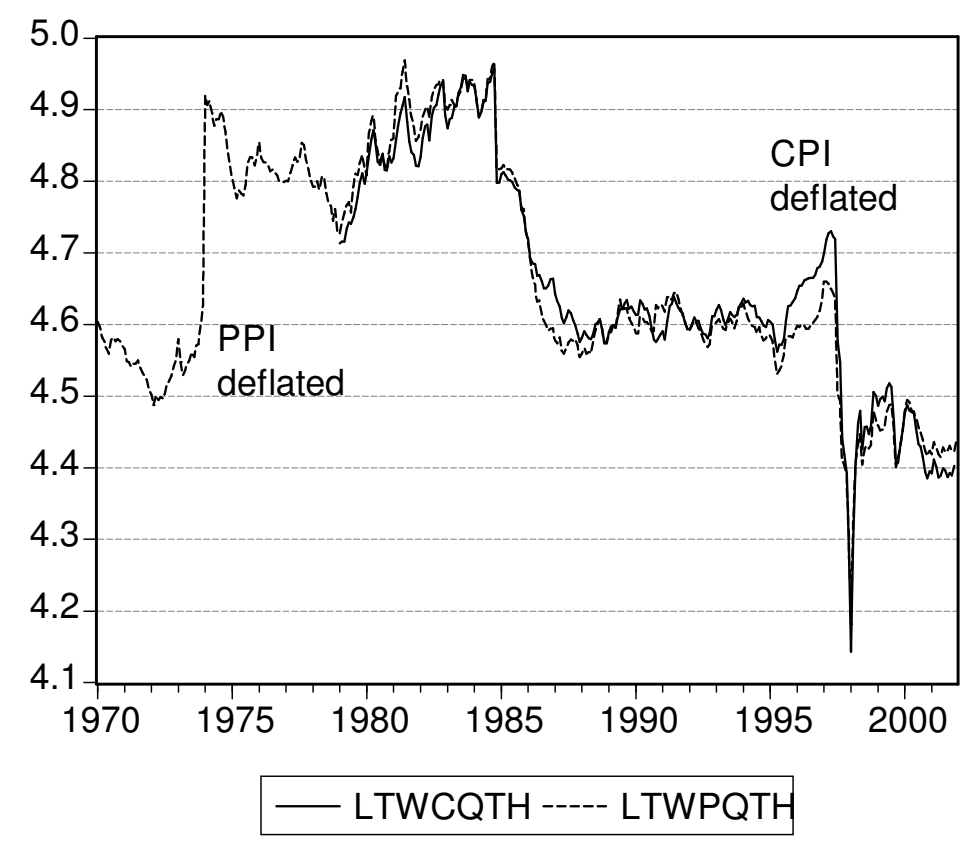

Figure 12: Thai Baht CPI and PPI Deflated Indices 


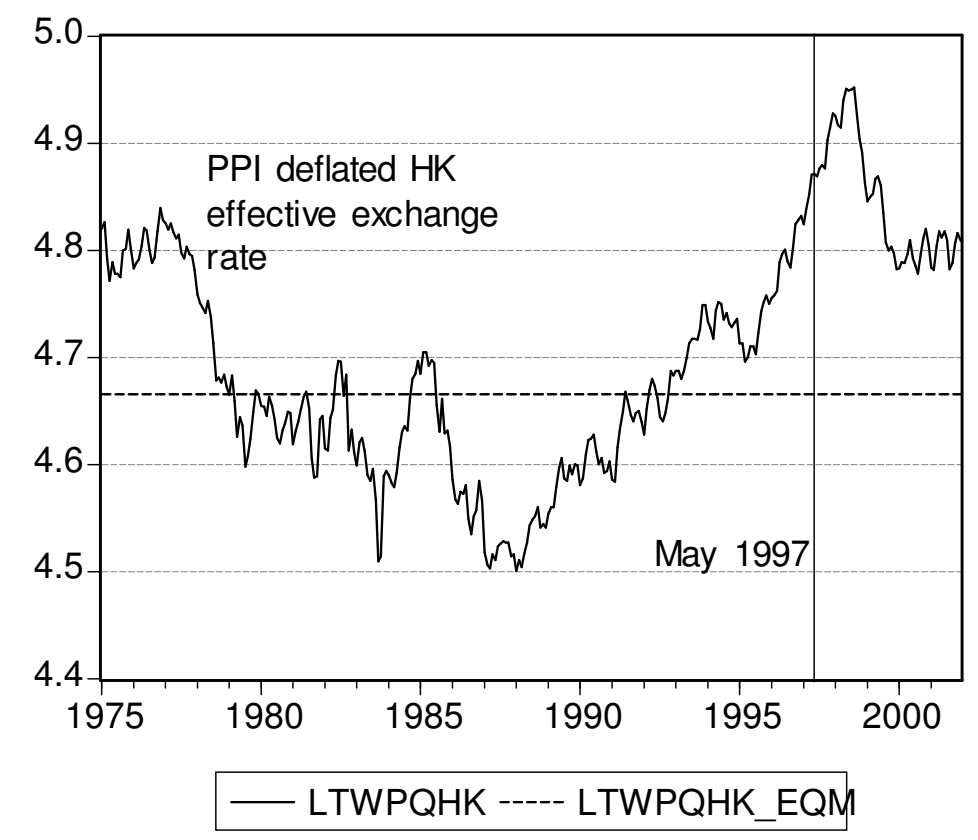

Figure 13: Hong Kong Index and Estimated PPP

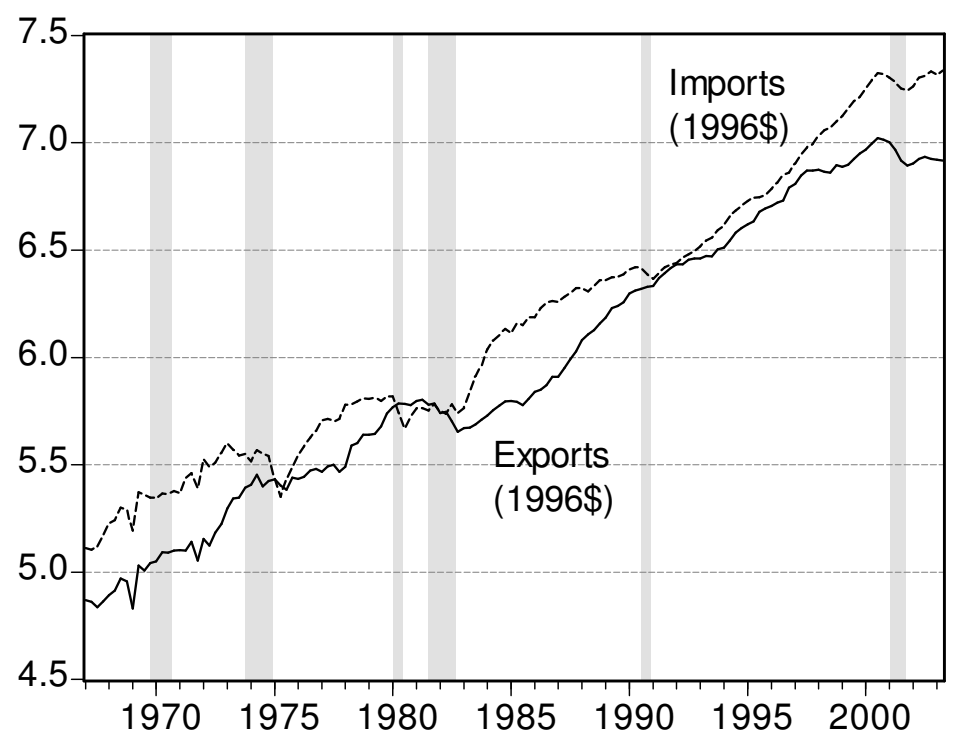

Figure 14: Exports and Imports of Goods and Services, in log chained 1996\$, and recession dates (shaded areas). Sources: BEA and NBER. 


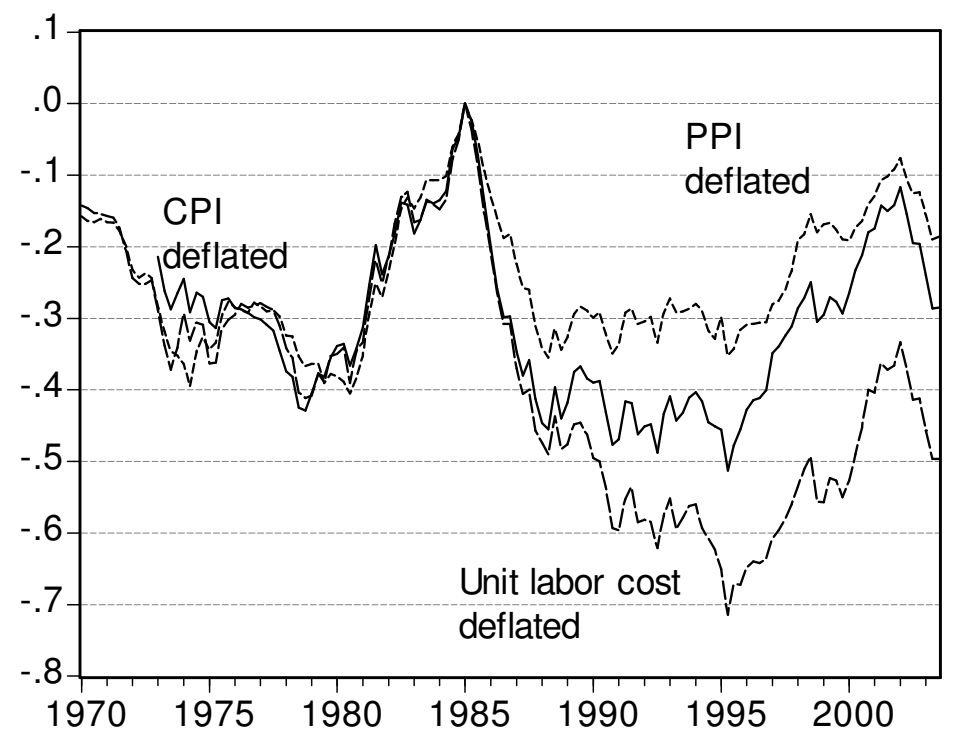

Figure 15: Indices of the U.S. Dollar Effective Exchange Rate (in logs, 1995q1=0). Source: Federal Reserve Board, J.P. Morgan and IMF.

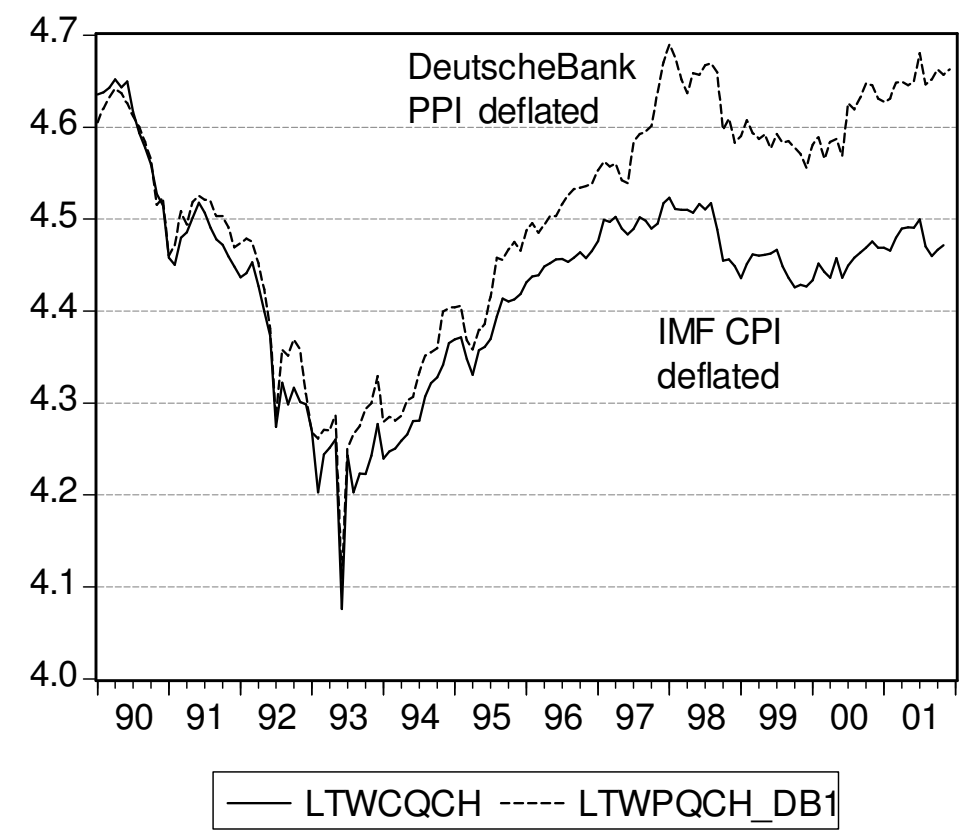

Figure 16: Comparison of IMF and DB Chinese Real Exchange Rate Series 